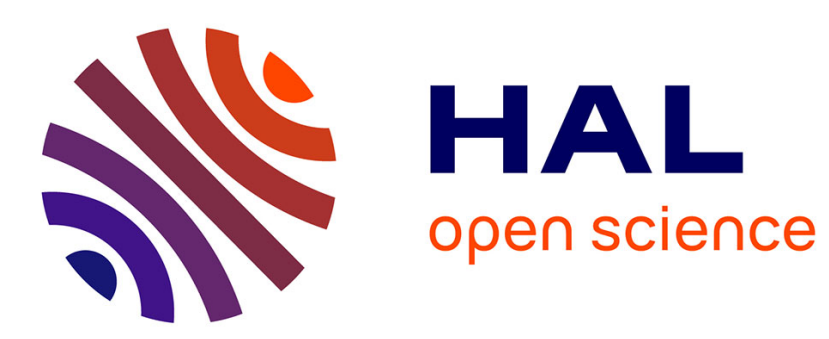

\title{
EGrowth: A global database on intraspecific body growth variability in earthworm
}

\author{
Jérôme Mathieu
}

\section{To cite this version:}

Jérôme Mathieu. EGrowth: A global database on intraspecific body growth variability in earthworm. Soil Biology and Biochemistry, 2018, 122, pp.71-80. 10.1016/j.soilbio.2018.04.004 . hal-02138395

\section{HAL Id: hal-02138395 https://hal.sorbonne-universite.fr/hal-02138395}

Submitted on 23 May 2019

HAL is a multi-disciplinary open access archive for the deposit and dissemination of scientific research documents, whether they are published or not. The documents may come from teaching and research institutions in France or abroad, or from public or private research centers.
L'archive ouverte pluridisciplinaire HAL, est destinée au dépôt et à la diffusion de documents scientifiques de niveau recherche, publiés ou non, émanant des établissements d'enseignement et de recherche français ou étrangers, des laboratoires publics ou privés. 
a Sorbonne Université, CNRS, UPEC, Paris 7, INRA, IRD, Institut d'Ecologie et des Sciences de

8 Corresponding author:

9 Jérôme Mathieu, jerome.mathieu@upmc.fr

Abstract

13 Earthworms play a key role in soil and ecosystem functioning. Predicting their abundance and spatial

14 distribution is required to understand their ecological role. There is growing evidence that

15 mechanistic models of earthworm population dynamics are promising tools to tackle this issue.

16 However, this approach requires a fair amount of data because it explicitly integrates the three

17 fundamental biological processes: growth, reproduction and mortality. Hitherto, the lack of comprehensive databases on life history parameters related to these three processes hampered the widespread development of mechanistic earthworm population dynamics models. As a consequence, predicting earthworm abundance in a variety of conditions across species is still difficult. 
The clear bottleneck for making progress is the lack of databases on the intraspecific variability of earthworm life history traits in response to environmental conditions. Data related to body growth and body size are critical because body size largely determines reproduction and mortality rates. Body growth is therefore the backbone of mechanistic models of earthworm population dynamics. Here I present EGrowth, the first comprehensive database on intraspecific variability of earthworm body growth in relation to environmental conditions. The EGrowth database contains 1073 growth curves of 51 species of earthworms, representing 16002 measures of body mass. It covers publications on earthworm body size from 1900 to 2016 . The environmental conditions in which the growth curves were produced are also reported. The database is open access and can be browsed from a graphical user interface. EGrowth will be updated regularly in the future as new studies are published. I propose a standardized framework for reporting future data on body growth of earthworms.

Key words:

Body size; Life history traits; Interspecific variability; Intraspecific trait variability (ITV); Database; Allometry

1. Introduction

41 Earthworms play an important role in soil functioning (Lavelle, 1988). For instance, they modify soil 42 structure, bulk density and aggregate stability, with direct consequences for water infiltration rates 43 and hydrological conductivity (Blanchart, 1992; Bossuyt et al., 2005; van Schaik et al., 2014). They

44 also affect nutrient and carbon fluxes through their effect on decomposition and microbial activity 
(Pashanasi et al., 1996; Richardson et al., 2016). These modifications impact vegetation (De Deyn et al., 2003; Hattenschwiler and Gasser, 2005; Laossi et al., 2009) and climate dynamics (Lubbers et al., 2013; Zhang et al., 2013). A number of studies have shown that all these effects quantitatively depend on earthworm abundance and traits, which are themselves constrained by environmental conditions (e.g. Jouquet et al., 2008; van Schaik et al., 2014). Understanding how the environment impacts earthworm abundance and traits in a quantitative way is therefore a key requisite for a better grasp of their role in soil functioning. However, predicting earthworm abundance and traits in a specific context is very challenging because soils are extremely heterogeneous even at fine scales. In addition, ecological preferences vary among species. A major challenge is thus to develop a quantitative understanding of earthworm ecology for predicting earthworm abundance and traits in relation to ecological conditions.

A promising approach for tackling this issue is the development of process based models (Jager et al., 2006; Kooijman, 2010). They have been used for a variety of purposes such as understanding the spatial structure of earthworm populations, the impact of earthworms on infiltration rates, or the effect of pesticides on earthworm population dynamics (Barot et al., 2007; Baveco and De Roos, 1996; Schneider and Schroder, 2012; Vorpahl et al., 2009). These models mimic growth, reproduction and death of individuals or cohorts, in order to predict population dynamics. They require a fair amount of data to parametrize the modelled processes, which has been identified as the primary bottleneck for the development of such approaches (Schneider and Schroder, 2012). Data on body growth variability, and thus on intraspecific body size variability (IBSV), are critical because body size determines the rate of reproduction and life span (Brown et al., 2004). Indeed cocoon production, cocoon hatchability, food consumption, and longevity all depend on the body size of earthworms (Daniel, 1990; Michon, 1954). In turn, the population dynamics and ecological effects of earthworm are also related to their body size (Brown et al., 2004). 
In order to build mechanistic models of body growth, we need to estimate the effects of the environment on growth patterns. For this we need databases that document the respective effect of a variety of environmental factors. This kind of data is typically available from experiments in controlled conditions, where only the factor(s) studied vary. A large number of studies have reported this type of experiments on earthworms. However, as far as I am aware, there is no comprehensive database compiling data on the effect of the environment on intraspecific body size variability in earthworms.

Building a database on IBSV that covers a wide spectrum of earthworm species is challenging in several aspects. The first inherent difficulty is that the shape of body growth curve varies among studies (Grimm et al., 2014). In particular, growth curves can be non-monotonic because body size can regress, present oscillations or can follow a staircase shape (Lakhani and Satchell, 1970; Michon, 1954; Tondoh and Lavelle, 1997). Hence, data on body size without reference to the shape of growth pattern have limited utility for modelling the effect of the environment on body size. The ideal structure of a global database should include this diversity of growth patterns, and should enable generalization to species for which growth form has not been measured so far. A simple way to achieve this is to build IBSV databases on body growth curves - i.e. ontogenetic growth. Body growth curves are measures of body mass at different times on the same individual or on the same population. This approach allows the modelling of body growth and the calculation of a variety of body growth parameters that can be compared among ecological conditions and across species (West et al., 2001).

A second difficulty for building databases on IBSV is the retrieval of the conditions during growth. Having this information is critical for identifying the drivers of IBSV, and to quantify their effect on body size. This information also allows parametrizing reaction norm functions, which are mathematical models that predict body growth in relation to environmental conditions such as 
conditions in reports on body growth of earthworm is however challenging because there are no standardized guidelines to present this type of information. As a result, these data are often missing or dispersed within the documents.

Lastly, the data by themselves are difficult to access because they are scattered in many articles, in different journals and in different kind of reports. The title and summary of the documents often do not reveal the presence of data on body growth. Growth curve data were often published in early articles that are not recorded in search engines and not available in electronic format. Data are usually difficult to reuse because they are presented only in graphical form, without the corresponding raw data. This implies a manual digitalization of the figures to reuse the data. Furthermore, centralizing existing data on body size and growth of soil animals is necessary, not only for making these data easily reusable, but also to ensure that these data will not be definitively lost in the future.

In this paper, I present the EGrowth database. The database compiles existing data about body growth of 51 species of earthworm. It actually contains more than 16000 body mass measures, representing more than 1000 growth curves. The database is open access and can be accessed in a variety of manner. It can be downloaded or accessed through a Graphical Interface (GUI) from R or from internet. This database will be updated in the future with new studies. In order to facilitate this process, I propose a standardized framework for reporting future data on body growth of earthworms.

\section{Material and methods}

\subsection{Database construction}

Data were searched in articles published in peer reviewed journals and in PhD theses from 1900 to 2016. Articles were searched in different ways, with the goal to be as exhaustive as possible. An 
intensive internet search was carried out through different databases, mainly Web Of Science, Scopus, Google Scholar and Researchgate. References cited within the articles were also searched for online and in various libraries in France (MNHN and IRD Bondy) and USA (UCSB and Stanford). Key words such as earthworm growth rate, body size, and ones related to earthworm ecotoxicology - a field which offers a large amount of data- were used to retrieve publications. In addition, all issues from the most relevant journals - Pedobiologia, Soil Biology \& Biochemistry, Biology and Fertility of Soils, Applied Soil Ecology and Megadrilogica were checked manually through table of contents for articles containing data about earthworm growth rate. Articles that were not available in a digital format were scanned, and the text was extracted through an OCR process (Optical character recognition). Then figures and tables with relevant data were extracted, digitalized with the software DataThief, and exported into spreadsheets. Point data from figures were reported with their associated error bars when available. Error bars were converted to Standard Error bars. Metadata such as the number of measures per point, temperature and treatments were searched for manually in the text and included in the database, when available. The authors of the articles with missing data were contacted in order to complete the database. All articles were stored as pdf files in an online folder and can be accessed upon request.

Overall, 414 publications were analysed, from which only the ones with at least four monitoring dates were retained. As a consequence, many articles, in particular the ones that used Instantaneous Growth Rate (IGR) - the difference of (log) body mass between two dates -, were not considered. Studies that used adults at the beginning of the experiments were also discarded. At the end 162 publications were used to build the database. The list of articles is given in supplementary material. 
141 The database is organized in three tables (Fig. 1), which are described in detail in supplementary

142 material.

143 [Figure 1]

$144 \quad$ 2.2.1 File "curves.txt"

145 This table stores the growth curve data points (16002 entries, 4 columns). Each entry is the

146 individual or average biomass of a batch of earthworms at a given time in a given experiment, with

147 the standard error of the mean of the biomass, when available. Each growth curve has a unique

148 identifier called "CURVE_ID". All points with the same CURVE_ID belong to the same growth curve.

149 Be aware that the column "time" is in most cases not the age of animals but the time since the

150 beginning of the experiment.

$151 \quad 2.2 .2$ File "curves_md.csv"

152 This table (1073 entries, 30 columns) describes the environmental conditions in which each growth

153 curve was produced. This table is linked to the "curves.txt" file through the CURVE_ID field. This field

154 allows the user to retrieve the environmental conditions in which each curve was produced. For

155 each curve the name of the species studied, the types of factors that were tested in the experiment,

156 the level of the factors, the intra and eventually interspecific earthworm density in the container,

157 the room temperature, the soil moisture, the geographic origin of the individuals, the food and the

158 substrate can be obtained. In experiments with fluctuating temperature, the average temperature

159 was reported. There is also a "REF_ID" field that indicates the source of the data. This field is used to

160 join this table to the file "references.csv".

2.2.3 File "references.csv"

162 This table describes the documents from which the growth curves come from. It is linked to the "curves_md.csv" file through the "REF_ID" field. It contains also the DOI of sources, when available. 
164 This file is essential for tracking the origin of the data and for reproducibility of analyses. Only

165 published data were included in the database. There are 162 entries and 7 columns in this table.

\subsubsection{Database access}

167 The database is open and can be accessed in a variety of manners that are presented in details in the

168 user guide provided in supplementary material.

169 You can access it through a Graphical User interface from internet at http://www.jerome-

170 mathieu.com/open-data/egrowth or from the R software console by typing:

171 [code]

172 if (!require('shiny ')) install.packages('shiny');

173 library(shiny);

174

runGitHub("EGrowth", "JeromeMathieuEcology")

175 [end of code]

177 Alternatively you can download the database in your computer from Zenodo and access it through $\mathrm{R}$.

181 A minimal example of the database usage is presented now.

182 This example assumes that the database (the three files "curves.txt", "curves_md.csv" and "references.csv") are stored in the R working directory. The first step is to read the data. 
growth <- read.table("curves.txt", $h=T$, na.strings = "na",sep = "\t")

191 Then one way to proceed is to merge the tables based on field "CURVE_ID", which is the growth

192 curve unique identifier:

193 [code]

194 EGrowth <- merge(growth, EGrowth_metadata, by = "CURVE_ID")

195 [end of code]

196 We can plot all curves of a species of interest.

197 Example with Drawida willsi:

198 [code]

199 if (!require('lattice ')) install.packages('lattice');

200 library(lattice)

201 with(EGrowth[EGrowth\$species =="Drawida willsi",],xyplot(bm time|CURVE_ID, 
206 [end of code]

207

208 [Figure 2)

209

210 Then you can retrieve the environmental data by typing:

211 [code]

212 EGrowth_metadata[EGrowth_metadata\$species =="Drawida willsi",]

213 [end of code]

214

215 More examples and the code of all the analyses presented in this paper are given in the User Guide.

216 The code of the GUI is provided in the GitHub repository:

217 https://github.com/JeromeMathieuEcology/EGrowth

218

219 3. Coverage of EGrowth

220 At the present time, the EGrowth database contains 1073 growth curves, made of 16002

221 measurements of biomass. These data come from 162 publications.

$222 \quad 3.1$ Temporal dynamics of publication 
223 No data were found between 1900 and 1953. The production of data on earthworm body growth

224 started in 1954, with the seminal PhD thesis of Jean Michon (Michon, 1954). From this time

225 onwards, the number of published growth curves increased exponentially until the 90's (Fig. 3a).

226 During this period, five other theses focused on earthworm body growth and life history traits. After

227 the 90's, the publication rate of growth curves slowed down. The last past ten years showed a

228 dramatic reduction in the production of new data. In particular the number of species covered has

229 not increased since 2011 (Fig. 3b).

$230 \quad$ [Figure 3]

231

3.2 Species covered

232

Growth curve data on 51 species are included in EGrowth (Fig. 4). The most documented species

233

were by far Eisenia foetida ( $n=244)$, Lumbricus terrestris $(n=131)$, Eisenia Andrei $(n=87)$,

234

Aporrectodea caliginosa ( $n=74)$ and Lumbricus rubellus ( $n=70)$ (Fig. 4). The criteria for studying a

235 specific species was rarely reported, except for E. foetida, which is a model species in ecotoxicology

236 (OECD, 1984). In the top five studied species, two are considered as global invasive species (L. terrestris and L. rubellus). Overall, only one endemic species (Hormogaster elisae, Spain) was studied. There are no data for endangered species such as Megascolides australis, the giant gippsland earthworm from Australia (Van Praagh, 1992), or Driloleirus americanus, the giant Palouse earthworm from USA (Sánchez-de León and Johnson-Maynard, 2009).

$241 \quad$ [Figure 4]

\subsection{Locations covered}

Growth curves in EGrowth were issued from 86 different sites spread around the world (Fig. 5). Most of the data were produced in Europe and in India. At the moment, no dataset is available from Russia, China and central Africa. Data from Russia and China probably exist, but were not found 
because they are not yet available in English. There are much more body growth curves from

temperate areas $(n=693)$ than from tropical $(n=283)$ or from Mediterranean climates $(n=97)$.

$248 \quad$ [Figure 5]

3.4 The general shape of body growth curves in earthworm

The shape of body growth curves from birth to death has been poorly documented so far. The most complete work regarding this topic is the PhD of Michon (1954). He compared the pattern of body growth of 14 species, from birth to death, with extremely frequent measures of body mass. He identified several stages in the life cycle of earthworm based on the shape of the logged body mass growth curve. In particular, he showed the existence of a senescence phase, which has been poorly documented since then. From this work and from more recent ones, we can define a general pattern of earthworm growth shape (Fig. 6a).

After birth (B), juveniles (J) usually follow a lag phase, then a steep, exponential or linear, growth. In long living species, the J phase can show a staircase shape pattern (Lakhani and Satchell, 1970). When sexual maturity is attained, adults enter the reproduction stage (R) and growth is strongly reduced and sometimes becomes negative. After some time, adults enter a senescence stage (S), during which time body size decreases and sexual organs disappear.

In most of the publications, growth was monitored only during a fraction of lifespan. Three broad monitoring schemes can be identified (Fig. 6b). difference of (usually log) body mass between two dates (e.g. Eriksen-Hamel et al., 2009). The monitoring generally occurs during the juvenile stage. The exact age at the beginning and at the end 
of the monitoring vary among studies and is often not reported. This kind of data was not included in EGrowth database because it is not suitable for fitting growth rate models.

271 The monitoring scheme type 2 is the most common after type 1. It refers to cases were biomass was

272 measured on more than four occasions, the first measurement being during the juvenile stage, but 273 not at birth. Monitoring ends either during the juvenile stage (J monitoring scheme) or during 274 reproduction stage (JR monitoring scheme). Measures were rarely taken until senescence (JS monitoring scheme) or until death (JD).

In the third broad monitoring scheme, monitoring started at cocoon hatching. This monitoring scheme is the most informative because the age of the individuals is known. Unfortunately, this monitoring scheme is also the least frequent, probably because of the fact that obtaining a batch of synchronized hatchlings with the same age is difficult. Some techniques such as storing cocoons at low temperature has been proposed to solve this difficulty (Bouwman, 1998). However, it still requires to breed the individuals in advance, to wait for cocoon production and for hatching. This can be a severe difficulty in species with slow population dynamics. Within this monitoring scheme, a variety of monitoring length also exists. A number of studies only cover the juvenile stage (BJ). These studies are particularly useful to estimate the age of the individuals in the monitoring scheme type two, in which age at the beginning of the monitoring is not reported. However BJ data are usually not sufficient to estimate the shape of the growth shape without making strong assumption about the shape of the growth curve. In BR monitoring scheme, individuals are monitored until their mature stage, before senescence occurs. In this case, the growth curves are usually monotonic: there is no decrease in body mass. This is the most frequent sampling design in monitoring scheme type three. A very limited number of studies monitored growth rate from birth to senescence (BS) or from birth to death $(B D)$. These monitoring schemes are however the most informative as they give estimates of life spam and the complete shape of the body growth curve. 
Overall, the great majority of studies in EGrowth lasted between 100 and 200 days (Fig. 7a), but some lasted over 900 days (e.g. Mulder et al., 2007). Most sampling frequency fell into one of the three following classes: every week, every two weeks, or every month (Fig. 7b).

\section{[ Figure 7]}

\subsection{Drivers of body growth}

Nearly all studies were performed in controlled conditions in the laboratory. Only seven growth curves, all from temperate areas, were obtained in the field (Table 1). In the laboratory, by far the two most frequently documented factors are the type of food provided (368 curves) and the toxic effect of a variety of products ( 330 curves). These experiments typically come from studies on vermicomposting and from ecotoxicology. The effect of air temperature (140 curves) and density (134 curves) are also well studied. All other factors are much less well studied. Surprisingly, the effect of soil properties on earthworm growth has been poorly studied (48 curves), whereas it would greatly help to understand the distribution of earthworm species in nature. Overall, 172 curves comes from experiments that tested two or more factors.

\section{[Table 1]}

In ecotoxicology studies, the most frequent treatments are related to the type of waste used as substrate for growth, manure being the most studied (Table 2). The effect of copper and cadmium are the most documented among metals, while Moxidectin, Glyphosate and Dieldrin are the most studied among pesticides. 
The absence of a general framework to report data on growth has resulted in a heterogeneity of available information among studies in the EGrowth database. This has occasionally resulted in the discarding of growth curves because of the absence of critical information. It has also resulted in missing values in the database, which limits the possibilities of disentangling the effect of different factors, like temperature and humidity. This issue could easily be avoided in the future if simple guidelines were followed systematically when reporting results. The general good practices on how to report data for their reuse in meta-analyses have been proposed in various articles and are summarized by the FAIR principle: Findable, Accessible, Interoperable and Reusable (Gerstner et al., 2017; Penev et al., 2017; White et al., 2013; Wilkinson et al., 2016). Here I focus on the specific aspects in reporting growth curves for their easy re-use and integration in databases. I propose a tentative template for reporting such type of results, accompanied by a To Do checklist

330 (Supplementary material).

It is critical to clarify as much as possible the experimental design. For this, four components need to be clearly explained: $1^{\circ}$ the type of treatments that vary between curves, if any (e.g. temperature or food). $2^{\circ}$ the treatment levels for each treatment (e.g. for temperature: $5^{\circ} \mathrm{C}, 15^{\circ} \mathrm{C}, 25^{\circ} \mathrm{C}$ ). If there are more than one factor, the combination of levels covered (full factorial, incomplete design) must be specified. $3^{\circ}$ the number of independent measures (replicates) per level of treatment. This is usually the number of containers per level of treatment. $4^{\circ}$ the number of individuals per replicate: density within containers (e.g.: 3 ind.replicate-1). 
If you will allow it; I would like to remind you here of a few points on experimental design. First, individuals in the same container cannot be considered as independent because of block effects. Using the individuals' data without accounting for this block effect leads to pseudo replication (Hurlbert, 1984). Indeed, all individuals in the same container are affected similarly by any variation of the container, and hence are not independent. When it is possible to track individuals separately, we can use the raw data and integrate a block effect (i.e. container) in the analysis. However, for earthworms, this is generally not possible without using tags (Mathieu et al., 2017). The correct procedure in general is thus to use the averaged biomass by replicate, but this results in a significant loss of statistical power. In order to circumvent this problem, a solution is to distribute individuals in as many as possible separate replicates, rather than grouping them in a limited number of replicates. This maximizes the power of the study without increasing its cost (the number of individuals does not change). Following these lines, it is more efficient to put only one individual per container rather than several ones. Beyond improving the power of statistical tests, it removes all effects of density dependence such as competition and reproduction, which can interfere with the treatments, and which can vary according to species (Uvarov, 2009). In the end, it gives a better picture of the effect of treatments on growth, all other things being equal. Replicates with only one individual per container thus facilitate the comparison among studies and among species.

\subsection{What is biomass and how to report it}

Reporting biomass is not as trivial as it can seem at first. Indeed biomass can change significantly with body moisture, gut content, and fat content, without having an ecological or evolutionary significance. Hence, it is important that the type of biomass reported is clearly mentioned. The ideal unit for comparing studies is dry weight of gut voided individuals. This removes the issues of body moisture and gut content, which represent a large proportion body weight and which can vary substantially regardless of dry biomass. However, this unit is not practical because it requires gut voiding then killing a fraction of the individuals at each monitoring event. 
A good compromise is to report fresh biomass of non-gut voided individuals, and to measure separately, on a batch of individuals of varying size, gut content as a function of fresh biomass (e.g. Bolton and Phillipson, 1976; Curry and Bolger, 1984), and the relationship between the biomass of fresh gut voided and dry gut voided individuals (Saussey, 1966).

Whatever the type of biomass reported, it is crucial to clearly define it, and to use appropriate terminology and units. For instance, in a number of publications the word "growth" is used instead of biomass. Growth is a variation of biomass over a period of time (units can be mg.day.-1), not a biomass at a given time (units: $\mathrm{mg}$ ). parameters that depend on age, such the age at growth spurt - the maximum growth rate (Parks, 1982). These kind of parameters are sometimes the only ones affected by a treatment. For instance, a particular treatment can produce a shift in phenology such as a decrease of age at maturity, and change population dynamics, without impacting maximal body size.

Reporting age is also needed for comparing growth models across studies. Indeed, parameters in growth models are often age dependent. Hence, they can only be correctly estimated if age is given in data, rather than time since the beginning of the experiment. This is particularly important when the study do not start from the birth of the individuals. In such case, if the age at the beginning of the growth curve is not given, it is difficult to translate the time axis into age. This is particularly true for studies based on IGR. Without age and weight, it is not possible to integrate IGR data in growth curve databases. monitoring can be very helpful to rescale the time axis into age. 
Phenology is an important aspect of body growth patterns. Indeed a number of standard indicators, such as biomass at maturity, are defined in relation to the stage of the individuals. Changes in stages can be indicated by arrows on curves (Klok and de Roos, 1996) or directly as a table giving the proportion of individuals at each stage, at each date (e.g. Elvira et al., 1996). When data are presented in an aggregated way, the most useful information is the age at which $50 \%$ of the individuals reached a given stage. Reporting the death or quiescence of animals is also interesting because it allows computing the mortality curve, and to take into account density dependent processes. This can be indicated by a sign such as stars on graphs, or directly in the raw data.

\subsection{Reporting taxonomy}

The correct identification of species is critical for comparing data and building databases. However, taxonomy is still being actively updated, with sometimes major revisions. Most earthworm classifications has been developed on morphological or anatomical traits, and recent molecular studies are revising many taxa (e.g. Csuzdi et al., 2017; Domínguez et al., 2015). The problem is particularly accurate for growth experiments because identifying living individuals is very difficult, and in most cases not possible until maturity. This might not be problematic to compare treatments within a study, but it becomes a matter of importance when comparing results across studies and across species. Most taxonomical errors probably consist in aggregating different species into a single species, because of cryptic species. This leads to artificially increasing intraspecific variability while decreasing interspecific differences. The problem occurs even in the most studied species such as E. foetida, L. terrestris, and A. caliginosa, whose taxonomical status has been revised several times. As it is almost impossible to check the identification of species in previous studies, caution should be taken in any comparative analysis. The only option to circumvent this difficulty in future 
412 studies is to systematically store a few individuals from each study in pure alcohol, and to check

413 identifications with molecular techniques. This is necessary to reach a homogenous and

414 standardized classification across studies.

4154.6 Reporting the conditions of the experiments: the need for metadata

416 Understanding the drivers of IBSV requires that environmental conditions in which data were

417 acquired are reported. This information should cover at minimum the air temperature, the soil pH,

418 soil moisture, expressed in clear units, the number of individuals per container, and the dimensions

419 of the container. Soil humidity in particular is often poorly reported although it is a critical condition

420 for earthworm growth. The type of food, its amount, and the frequency at which it was provided

421 should also be mentioned. These data should ideally be given for each curve and, if possible, for

422 each measurement date. Indeed the conditions such as temperature or the number of individuals

423 sometimes vary during the experiments.

4.7 Reporting raw data

An obvious limiting factor for building databases on body growth curves is that data are usually only

427 presented graphically. Extracting data from graphs is tedious, time consuming and needs to be done

428 by a careful and experienced worker. In addition, digitalizing growth curves is sometimes not

429 possible when data overlap, or when artwork resolution is too low. A much more efficient way would be to publish the data also in tables. Ideally, data should be stored in long term repositories such as Zenodo or Figshare, which offer four key features to reuse data in the future: long term storage, easy identification and citation of data trough unique identifiers (DOI), easy finding of datasets through key words in metadata, and easy download of data. Alternately, raw data can be 
use non-proprietary format such as comma separated text (.csv) or tab separated text (.txt), because they will always be readable from all platforms.

It is much more useful to publish the raw data of each growth curve or each replicate, rather than their average. It clarifies the experimental design. It gives more power to analyses and simplifies them. Indeed, it is much straightforward to include all data in analysis than using aggregated data, which must be weighted by error bars and sample size. In addition, it reduces the digitalization errors, particularly when data overlap in graphs.

\subsection{Report error bars and their unit}

Despite previous reminders about the necessity of reporting error bars in graphs (e.g. Cumming et al., 2007), they are still absent in a number of publications. When reporting averaged data is the only possibility, it is vital to show the error bars of the mean. It is also critical to clearly mention the type of error bar that was used (e.g. standard error, standard deviation, confidence interval) and the sample size, otherwise errors bars cannot be used.

Conclusion

The EGrowth database shows that a large amount of data on earthworm body growth is already published. By centralizing these data, EGrowth should help the development of process based models of earthworm ecology. EGrowth also reveals knowledge gaps that challenge the applicability of such models to real situations in nature. In particular, there is a clear lack of data from the field. This kind of data is critical for assessing the performances of models. In addition, the effect of critical environmental factors for earthworm growth, such as soil properties and soil humidity, have been little studied so far. Lastly, little is known about rare species that are not dominant, particularly regarding large or endemic species. In order to integrate new data, EGrowth will be updated in the future. For this, a framework to report future data on earthworm body growth is proposed. 
461 The author would like to thank all the authors who kindly replied to his emails and furnished additional details on their data, and Naoise Nunan for English editing.

References

Angilletta, J.M.J., Steury, T.D., Sears, M.W., 2004. Temperature, Growth Rate, and Body Size in Ectotherms: Fitting Pieces of a Life-History Puzzle1. Integrative and Comparative Biology 44, 498-

467 509.

Barot, S., Rossi, J.-P., Lavelle, P., 2007. Self-organization in a simple consumer-resource system, the example of earthworms. Soil Biology \& Biochemistry 39. individual-based modelling approach. Journal of Applied Ecology 33, 1451-1468. of a destructured savanna soil under field conditions. Soil Biology and Biochemistry 24, 1587-1594.

474 Bolton, P.J., Phillipson, J., 1976. Burrowing, feeding, egestion and energy budgets of Allolobophora 475 rosea (Savigny) (Lumbricidae). Oecologia 23, 225-245.

477 earthworm casts. Soil Biology \& Biochemistry 37, 251-258. earthworms (Eisenia fetida). Biology and Fertility of Soils 27, 368:373. 

ecology. Ecology 85, 1771-1789. and systematics of native North American lumbricid earthworms (Clitellata: Megadrili). Plos One 12, e0181504.

Cumming, G., Fidler, F., Vaux, D.L., 2007. Error bars in experimental biology. The Journal of Cell Biology 177, 7-11.

Curry, J.P., Bolger, T., 1984. Growth, reproduction and litter and soil consumption by Lumbricus terrestris L. in reclaimed peat. Soil Biology \& Biochemistry 16, 253-257. Federal Insitute of Technology Zurich, Zurich, p. 77.

De Deyn, G.B., Raaijmakers, C.E., Zoomer, H.R., Berg, M.P., de Ruiter, P.C., Verhoef, H.A., Bezemer, T.M., van der Putten, W.H., 2003. Soil invertebrate fauna enhances grassland succession and diversity. Nature 422, 711-113.

Domínguez, J., Aira, M., Breinholt, J.W., Stojanovic, M., James, S.W., Pérez-Losada, M., 2015. Phylogenetics and Evolution 83, 7-19. Dendrobaena rubida in cow manure Mixed cultures with Eisenia andrei. Applied Soil Ecology 5, 97103. populations and growth rates related to long-term crop residue and tillage management. Soil \& Tillage Research 104, 311-316. 
Gerstner, K., Moreno-Mateos, D., Gurevitch, J., Beckmann, M., Kambach, S., Jones, H.P., Seppelt, R., 2017. Will your paper be used in a meta-analysis? Make the reach of your research broader and longer lasting. Methods in Ecology and Evolution 8, 777-784. Temperature on Metabolic Rate. Science 293, 2248-2251. database of European reptile species. Nature Conservation 9.

Hattenschwiler, S., Gasser, P., 2005. Soil animals alter plant litter diversity effects on decomposition. Proceedings of the National Academy of Sciences of the United States of America - biological sciences $102,1519-1524$. Hurlbert, S.H., 1984. Pseudoreplication and the Design of Ecological Field Experiments. Ecological Monographs 54, 187-211.

Jager, T., Reinecke, S.A., Reinecke, A.J., 2006. Using process-based modelling to analyse earthworm life cycles. Soil Biology \& Biochemistry 38, 1-6. Jouquet, P., Podwojewski, P., Bottineli, N., Mathieu, J., Ricoy Martinez, M., Orange, D., Tran, T.D., Valentin, C., 2008. Above-ground earthworm casts affect water runoff and soil erosion in Northern Vietnam. Catena 74, 13-21. Individual Growth and Reproduction in Lumbricus rubellus (Lumbricidae, Oligochaeta). Ecotoxicology and Environmental Safety 33, 118-127. University Press. 
525 Lakhani, K.H., Satchell, J.E., 1970. Production by Lumbricus terrestris (L.). Journal of Animal Ecology $52639,473-492$.

527 Laossi, K.-R., Noguera, D.C., Bartolomé-Lasa, A., Mathieu, J., Blouin, M., Barot, S., 2009. Effects of 528 endogeic and anecic earthworms on the competition between four annual plants and their relative 529 fecundity. Soil Biology \& Biochemistry 41, 1668-1673.

530 Lavelle, P., 1988. Earthworm activities and the soil system. Biology and Fertility of Soils 6, 237-251.

531 Lubbers, I.M., van Groenigen, K.J., Fonte, S.J., Six, J., Brussaard, L., van Groenigen, J.W., 2013. Greenhouse-gas emissions from soils increased by earthworms. Nature Climate Change 3, 187-194.

534 Ecology.

Michon, J., 1954. Contribution expérimentale à l'étude de la Biologie des Lumbricidae. Les variations pondérales au cours des différentes modalités du développement postembryonnaire. Faculté des sciences de Poitiers, Poitiers, p. 192.

Mulder, C., Hendriks, J., Baerselman, R., Posthuma, L., 2007. Age structure and senescence in longterm cohorts of Eisenia andrei (Oligochaeta: Lumbricidae). J Gerontol A Biol Sci Med Sci 62, 13611363.

541 OECD, 1984. OECD guidelines for testing chemicals. Test 207: earthworm acute toxicity test. Organization for Economic Co-operation and Development (OECD), Paris. 
Penev, L., Mietchen, D., Chavan, V.S., Hagedorn, G., Smith, V.S., Shotton, D., Ó Tuama, É., Senderov,

549 V., Georgiev, T., Stoev, P., Groom, Q.J., Remsen, D., Edmunds, S.C., 2017. Strategies and guidelines

550 for scholarly publishing of biodiversity data. Research Ideas and Outcomes 3.

551 Ray, C., 1960. The application of Bergmann's and Allen's rules to the poikilotherms. J Morphol 106,

$55285-108$.

553

Richardson, J.B., Renock, D.J., Görres, J.H., Jackson, B.P., Webb, S.M., Friedland, A.J., 2016. Nutrient and pollutant metals within earthworm residues are immobilized in soil during decomposition. Soil Biology and Biochemistry 101, 217-225.

Sánchez-de León, Y., Johnson-Maynard, J., 2009. Dominance of an invasive earthworm in native and non-native grassland ecosystems. Biological invasions 11, 1393-1401.

Saussey, M., 1966. Contribution à l'étude des phénomènes de diapause et de régénération caudale chez Allolobophora icterica : Savigny Oligochète lombricien. Faculté de sciences de Caen, p. 160. feedbacks with abiotic soil properties. Applied Soil Ecology 58, 29-36. the earthworm Hyperiodrilus africanus (Eudrilidae). European Journal of Soil Biology 33, 13-18. earthworm performance and ecosystem functioning. Pedobiologia 53, 1-27. Australis McCoy, 1878. Soil Biology and Biochemistry 24, 1363-1367. 
570 Vorpahl, P., Moenickes, S., Richter, O., 2009. Modelling of spatio-temporal population dynamics of

571 earthworms under wetland conditions-An integrated approach. Ecological Modelling 220, 3647-

5723657.

573 West, G.B., Brown, J.H., Enquist, B.J., 2001. A general model for ontogenetic growth. Nature 413,

$574 \quad 628-631$.

575 White, E.P., Baldridge, E., Brym, Z.T., Locey, K.J., McGlinn, D.J., Supp, S.R., 2013. Nine simple ways to

576 make it easier to (re)use your data. Ideas in Ecology and Evolution 6.

577 Wilkinson, M.D., Dumontier, M., Aalbersberg, I.J., Appleton, G., Axton, M., Baak, A., Blomberg, N.,

578 Boiten, J.-W., da Silva Santos, L.B., Bourne, P.E., Bouwman, J., Brookes, A.J., Clark, T., Crosas, M.,

579 Dillo, I., Dumon, O., Edmunds, S., Evelo, C.T., Finkers, R., Gonzalez-Beltran, A., Gray, A.J.G., Groth, P.,

580 Goble, C., Grethe, J.S., Heringa, J., 't Hoen, P.A.C., Hooft, R., Kuhn, T., Kok, R., Kok, J., Lusher, S.J.,

581 Martone, M.E., Mons, A., Packer, A.L., Persson, B., Rocca-Serra, P., Roos, M., van Schaik, R., Sansone,

582 S.-A., Schultes, E., Sengstag, T., Slater, T., Strawn, G., Swertz, M.A., Thompson, M., van der Lei, J., van

583 Mulligen, E., Velterop, J., Waagmeester, A., Wittenburg, P., Wolstencroft, K., Zhao, J., Mons, B.,

584 2016. The FAIR Guiding Principles for scientific data management and stewardship. Scientific Data 3,

585160018.

586 Zhang, W., Hendrix, P.F., Dame, L.E., Burke, R.A., Wu, J., Neher, D.A., Li, J., Shao, Y., Fu, S., 2013.

587 Earthworms facilitate carbon sequestration through unequal amplification of carbon stabilization

588 compared with mineralization. Nat Commun 4.

589

590 


\section{List of publications used to build the EGrowth database on earthworm body growth variability}

Contact: Jerome.mathieu@upmc.fr

\section{a) List of publications from which data were included in the EGrowth database}

1. Addison, J.A., Safety testing of tebufenozide, a new molt-inducing insecticide, for effects on nontarget forest soil invertebrates. Ecotoxicology and Environmental Safety, 1996. 33(1): p. 55-61.

2. Addison, J.A. and S.B. Holmes, Effect of two commercial formulations of Bacillus thuringiensi subsp. kurstaki on the forest earthworm Dendrobaena octaedra. Canadian Journal of Forest Research, 1996. 26: p. 1594-1601.

3. Almaro, A.P., Effecto de la temperatura sobre el crecimiento, consumo de tierra y fecundidad de la lombriz de tierra Pontoscolex corethrurus Müller, 1857 (Oligoqueto Glossoscolecidae), 1983, Escuela Nacional de Estudios Profesionales: Los Reyes Iztacala. p. 56.

4. Amoji, S.D., et al., Influence of regulated temperature on growth and reproduction of the epigeic earthworm, Perionyx excavatus. Journal of Environmental Biology, 1999. 20(3): p. 207-212.

5. Amoji, S.D., et al., Influence of seasonal environmental factors on growth and reproduction of the epigeic earthworm, Eisenia fetida (Savigny 1826). Journal of Environmental Biology, 2000. 21(1): p. 59-63.

6. Anderson, C.J., et al., Life-history effects of arsenic toxicity in clades of the earthworm Lumbricus rubellus. Environmental Pollution, 2013. 172: p. 200-207.

7. Arunachalam, S., Some aspects of the biology of a tropical earthworm Pontoscolese corethurus (of. muller). The journal of the Bombay Natural History Society, 1978. 75: p. 110114.

8. Barois, I., P. Lavelle, and K. Kajondo, Adaptive strategies and short-term effects of selected earthworm species, 1994.

9. Basha, P.M. and V. Latha, Evaluation of sublethal toxicity of zinc and chromium in Eudrilus eugeniae using biochemical and reproductive parameters. Ecotoxicology, 2016. 25(4): p. 802813.

10. Berry, E.C. and D. Jordan, Temperature and soil moisture content effects on the growth of Lumbricus terrestris (Oligochaeta: Lumbricidae) under laboratory conditions. Soil Biology \& Biochemistry, 2001. 33: p. 133-136.

11. Bindesb $\varnothing$ I, A., M.D. Bayley, C., and M. Holmstrup, Life-history traits and population growth rate in the laboratory of the earthworm Dendrobaena octaedra cultured in coppercontaminated soil. Applied Soil Ecology, 2007. 35: p. 46-56.

12. Bisht, R., et al., Reproductive potential of the earthworm Metaphire posthuma (Oligochaeta) in different food substrates. Tropical Ecology, 2007. 48(1): p. 107-114.

13. Boström, U., Growth of earthworms (Allolobophora caliginosa) in soil mixed with either barley, lucerne or meadow fescue at various stages of decomposition. Pedobiologia, 1987. 30: p. 311-321.

14. Boström, U. and A. Lofs-Holmin, Growth of earthworms (Allolobophora caliginosa) fed shoots and roots of barley, meadow fescue and luzerne. Studies in relation to particules size, protein, crude fiber content and toxicity. Pedobiologia, 1986. 29: p. 1-12. 
15. Bouwman, H., Evaluation of a technique to obtain development-stage-synchronised earthworms (Eisenia fetida). Biology and Fertility of Soils, 1998. 27: p. 368:373.

16. Bouwman, H. and A.J. Reinecke, $A$ defined medium for the study of growth and reproduction of the earthworm Eisenia fetida (Oligochaeta). Biology and Fertility of Soils, 1991. 10(4): p. 285-289.

17. Brunninger, B., R. Viswanathan, and F. Beese, Terbuthylazine and carbofuran effects on growth and reproduction within three generations of Eisenia andrei (Oligochaeta). Biology and Fertility of Soils, 1994. 18: p. 83-88.

18. Buch, A.C., et al., Life cycle of Ponstoscolex coerthurus (Müller, 1857) in tropical artificial soil. Pedobiologia, 2011. 54(s29): p. s19-s25.

19. Butt, K.R., An investigation into the growth and reproduction of the earthworm Lumbricus terrestris L. under controlled environmental conditions, 1990, Open University. p. 141.

20. Butt, K.R., The effects of temperature on the intensive production of Lumbricus terrestris (Oligochaeta: Lumbricidae). Pedobiologia, 1991. 35: p. 257-264.

21. Butt, K.R., Reproduction and growth of three deep-burrowing earthworms (Lumbricidae) in laboratory culture in order to assess production for soil restoration. Biology and Fertility of Soils, 1993. 16: p. 135-138.

22. Butt, K.R., Utilisation of solid paper-mill sludge and spent brewery yeast as feed for soildwelling earthworms. Bioresource Technology, 1993. 44: p. 105-107.

23. Butt, K.R., Reproduction and growth of the earthworm Allolobophora chlorotica (Savigny, 1826) in controlled environments. Pedobiologia, 1997. 41: p. 369-374.

24. Butt, K.R., Interactions between selected earthworm species: a preliminary, laboratory-based study. Applied Soil Ecology, 1998. 9: p. 75-79.

25. Butt, K.R., Food quality affects production of Lumbricus terrestris (L.) under controlled environmental conditions. Soil Biology \& Biochemistry, 2011. 43: p. 2169-2175.

26. Butt, K.R. and M.J.I. Briones, Life cycle studies of the earthworm Lumbricus friendi (Cognetti, 1904). Pedobiologia, 2011. 54, Supplement(0): p. S27-S29.

27. Butt, K.R., J. Frederickson, and R.M. Morris, The intensive production of Lumbricus terrestris L. for soil amelioration. Soil Biology \& Biochemistry, 1992. 24(12): p. 1321-1325.

28. Butt, K.R., J. Frederickson, and R.M. Morris, Effects of earthworm density on the growth and reproduction of Lumbricus terrestris L. (Oligochaeta: Lumbricidae) in culture. Pedobiologia, 1994. 38: p. 254-261.

29. Butt, K.R., J. Frederickson, and R.M. Morris, The life-cycle of the earthworm Lumbricus terrestris L. (Oligochaeta: Lumbricidae) in laboratory culture. European Journal of Soil Biology, 1994. 30: p. 49-54.

30. Chauhan, H.K. and K. Singh, Effect of tertiary combinations of animal dung with agrowastes on the growth and development of earthworm Eisenia fetida during organic waste management. International Journal of Recycling of Organic Waste in Agriculture, 2013. 2(1): p. 11.

31. Cluzeau, D., Structure et dynamique des peuplements lombriciens dans des systèmes tempérés anthropisés, 1992, Université de Rennes: Rennes, France. p. 182.

32. Cluzeau, D. and L. Fayolle, Croissance et fécondité de Dendrobaena rubida tenuis (Eisen, 1874), Eisenia andrei (Bouché, 1972) et Lumbricus rubellus rubellus (Hoffmeister, 1843) (Oligochaeta, Lumbricidae) en élevage contrôlé. Revue d'Ecologie et de Biologie du Sol, 1989. 26(1): p. 111-121.

33. Cluzeau, D., L. Fayolle, and M. Hubert, The adaptation value of reproductive strategy and mode in three epigeous earthworm species. Soil Biology \& Biochemistry, 1992. 24(12): p. 1309-1315.

34. Coulibaly, S.S. and I.A. Zoro Bi, Influence of animal wastes on growth and reproduction of the African earthworm species Eudrilus eugeniae (Oligochaeta). European Journal of Soil Biology, 2010. 46(3-4): p. 225-229. 
35. Curry, J.P. and K.E. Boyle, Growth rates, establishment, and effects on herbage yield of introduced earthworms in grassland on reclaimed cutover peat. Biology and Fertility of Soils, 1987. 3: p. 95-98.

36. Daniel, O., L. Kohli, and M. Bieri, Weight gain and weight loss of the earthworm Lumbricus terrestris L. at different temperatures and body weights. Soil Biology \& Biochemistry, 1996. 28(9): p. 1235-1240.

37. Di Masso, R.J., L.B. Marc, and N.R. Biasatti, Earthworm [eisenia foetida (Savigny)] growth in coypu and other animal faeces as nutritional substrata. Megadrilogica, 1997. 6: p. 105-112.

38. Dominguez, J., M.J.I. Briones, and S. Mato, Effect of the diet on growth and reproduction of Eisenia andrei (Oligochaeta, Lumbricideae). Pedobiologia, 1997. 41: p. 566-576.

39. Dominguez, J. and C.A. Edwards, Effects of stocking rate and moisture content on the growth and maturation of Eisenia andrei (Oligochaeta) in pig manure. Soil Biology \& Biochemistry, 1997. 29(3/4): p. 743-746.

40. Dominguez, J., C.A. Edwards, and J. Dominguez, The biology and population dynamics of Eudrilus eugeniae (Kinberg) (Oligochaeta) in cattle waste solids. Pedobiologia, 2001. 45(4): p. 341-353.

41. Domínguez, J., C.A. Edwards, and M. Webster, Vermicomposting of sewage sludge: Effect of bulking materials on the growth and reproduction of the earthworm Eisenia andrei.

Pedobiologia, 2000. 44(1): p. 24-32.

42. Edwards, C.A., Breakdown of animal, vegetable and industrial organic wastes by earthworms, in Earthworms in waste and environmental management, C.A. Edwards, Editor 1988, SPB Academic Publishing: The Hague, The Netherlands. p. 21-31.

43. Elvira, C., J. Dominguez, and M.J.I. Briones, Growth and reproduction of Eisenia andrei and E. fetida (Oligochaeta, Lumbricidae) in different organic residues. Pedobiologia, 1996. 40: p. 377-384.

44. Elvira, C., J. Dominguez, and S. Mato, The growth and reproduction of Lumbricus rubellus and Dendrobaena rubida in cow manure Mixed cultures with Eisenia andrei. Applied Soil Ecology, 1996. 5: p. 97-103.

45. Fayolle, L., et al., Influence of temperature and food source on the life cycle of the earthworm Dendrobaena veneta (Oligochaeta). Soil Biology \& Biochemistry, 1997. 29(3-4): p. 747-750.

46. Fernandez, R., et al., Life cycle and reproductive traits of the earthworm Aporrectodea trapezoides (Dugès, 1828) in laboratory cultures Pedobiologia, 2010. 53(5): p. 295-299.

47. Fernandez-Gomez, M.J., E. Romero, and R. Nogales, Impact of imidacloprid residues on the development of Eisenia fetida during vermicomposting of greenhouse plant waste. Journal of Hazardous Materials, 2011. 192(3): p. 1886-1889.

48. Fischer, E. and L. Molnar, Growth and reproduction of Eisenia fetida (Oligochaeta, Lumbricidae) in semi-natural soil containing various metal chlorides. Soil Biology \& Biochemistry, 1997. 29(3-4): p. 667-670.

49. Fisker, K., et al., Genetic adaptation of earthworms to copper pollution: is adaptation associated with fitness costs in Dendrobaena octaedra? Ecotoxicology, 2011. 20(3): p. 563573.

50. Flack, F.M. and R. Hartenstein, Growth of the earthworm Eisenia foetida on microorganisms and cellulose. Soil Biology \& Biochemistry, 1984. 16(5): p. 491-495.

51. Frenot, Y., Introduced populations of Dendrodrilus rubidus ssp. (Oligochaeta: Lumbicidae) at Crozet, Kerguelen and Amsterdam islands: effects of temperature on growth patterns during the juvenile stages. Soil Biology \& Biochemistry, 1992. 24: p. 1433-1439.

52. Garcia, J.A. and C. Fragoso, Growth, reproduction and activity of earthworms in degraded tropical open mined soils: laboratory essays. Applied Soil Ecology, 2002. 20: p. 43-56.

53. García, J.A. and C. Fragoso, Influence of different food substrates on growth and reproduction of two tropical earthworm species (Pontoscolex corethrurus and Amynthas corticis): The 7th 
international symposium on earthworm ecology $\cdot$ Cardiff $\cdot$ Wales $\cdot$ 2002. Pedobiologia, 2003. 47(5-6): p. 754-763.

54. Garcia, M.G., F. Mariño, and S. Mato, Effect of the diet on growth and reproduction of Eisenia andrei (Oligochaeta, Lumbricidae) reared in individual cultures. Pedobiologia, 1999. 43: p. 267-275.

55. García-Pérez, J.A., et al., Impact of litter contaminated with glyphosate-based herbicide on the performance of Pontoscolex corethrurus, soil phosphatase activities and soil $\mathrm{pH}$. Applied Soil Ecology, 2016. 104: p. 31-41.

56. Garg, V.K., et al., Growth and reproduction of Eisenia foetida in various animal wastes during vermicomposting. Applied Ecology and Environmental Research, 2005. 3(2): p. 51-59.

57. Garg, V.K., P. Kaushik, and Y.K. Yadav, Effect of stocking density and food quality on the growth and fecundity of an epigeic earthworm (Eisenia fetida) during vermicomposting. Environmentalist, 2008. 28: p. 483-488.

58. Gerard, B.M., The biology of certain British earthworms in relation to environmental conditions, 1960, University of London: London. p. 283.

59. Gilot-Villenave, C., Determination of the origin of the different growing abilities of two populations of Millsonia anomala (Omodeo and Vaillaud), a tropical geophageous earthworm. European Journal of Soil Biology, 1994. 39(3): p. 125-131.

60. Grumiaux, F., et al., Assessing the effects of $F B C$ ash treatments of metal-contaminated soils using life history traits and metal bioaccumulation analysis of the earthworm Eisenia andrei. Chemosphere, 2010. 79(2): p. 156-161.

61. Grumiaux, F., et al., Effect of fluidized bed combustion ashes used in metal polluted soil remediation on life history traits of the oligochaeta Eisenia andrei. European Journal of Soil Biology, 2007. 43(Supplement 1): p. S256-S260.

62. Gunadi, B., C. Blount, and C.A. Edwards, The growth and fecundity of Eisenia fetida (Savigny) in cattle solids pre-composted for different periods. Pedobiologia, 2002. 46(1): p. 15-23.

63. Gunadi, B. and C.A. Edwards, The effects of multiple applications of different organic wastes on the growth, fecundity and survival of Eisenia fetida (Savigny) (Lumbricidae). Pedobiologia, 2003. 47(4): p. 321-329.

64. Gunadi, B., C.A. Edwards, and C. Blount, The influence of different moisture levels on the growth, fecundity and survival of Eisenia fetida (Savigny) in cattle and pig manure solids. European Journal of Soil Biology, 2003. 39(1): p. 19-24.

65. Hallatt, L., S.A. Viljoen, and A.J. Reinecke, Moisture requirements in the life cycle of Perionyx excavatus (Oligochaeta). Soil Biology \& Biochemistry, 1992. 24(12): p. 1333-1340.

66. Hamoui, V., Life-cycle and growth of Pontoscolex corethrurus (Müller, 1857) (Oligochaeta, Glossoscolecidae) in the laboratory. Revue d'Ecologie et de Biologie du Sol, 1991. 1991(4): p. 469-478.

67. Hartenstein, R., E.F. Neuhauser, and E.G. Easton, Growth and fecundity of $F_{2}$ Eisenia foetida derived from $F_{1} S$, both reared in isolation from birth. Megadrilogica, 1982. 3: p. 185-187.

68. Helling, B., S.A. Reinecke, and A.J. Reinecke, Effects of the Fungicide Copper Oxychloride on the Growth and Reproduction of Eisenia fetida (Oligochaeta). Ecotoxicology and Environmental Safety, 2000. 46(1): p. 108-116.

69. Jeshika, M. and M. Lekeshmanaswamy, Effect of Pongamia Leaf Medium on Growth of Earthworm (Eudrilus eugeniae). International Journal of Scientific and Research Publications, 2013. 3(1): p. 1-4.

70. Kaplan, D.L., et al., Physicochemical requirements in the environment of the earthworm Eisenia foetida. Soil Biology \& Biochemistry, 1980. 12: p. 347-352.

71. Karmegam, N. and T. Daniel, Growth, reproductive biology and life cycle of the vermicomposting earthworm, Perionyx ceylanensis Mich. (Oligochaeta: Megascolecidae). Bioresource Technology, 2009. 100(20): p. 4790-4796. 
72. Kaushal, B.R. and S.P.S. Bisht, Growth and cocoon production of Drawidia nepalensis (Oligochaeta). Biology and Fertility of Soils, 1992. 14: p. 205-212.

73. Kaushal, B.R., S. Kalia, and S.P.S. Bisht, Growth and cocoon production by the earthworm Drawida nepalensis (Oligochaeta: Moniligastridae) in oak and pine litter. Pedobiologia, 1995. 39: p. 417-422.

74. Kaushal, B.R. and B. Kandpal, Growth and cocoon production by the earthworm Metaphire houletti (Oligochaeta) in different food sources. Biology and Fertility of Soils, 1999. 29: p. 394-400.

75. Klok, C., Effects of earthworm density on growth, development, and reproduction in Lumbricus rubellus (Hoffm.) and possible consequences for the intrinsic rate of population increase. Soil Biology \& Biochemistry, 2007. 39: p. 2401-2407.

76. Klok, C., et al., Assessing the effects of abiotic environmental stress on population growth in Lumbricus rubellus (lubricidae, oligochaeta). Soil Biology \& Biochemistry, 1997. 29(3/4): p. 287-293.

77. Klok, C., et al., Influence of clay content and acidity of soil on development of the earthworm Lumbricus rubellus and its population level consequences. Biology and Fertility of Soils, 2007. 43: p. 549-556.

78. Kostecka, J. and K.R. Butt, Ecology of the earthworm Allolobophora carpathica in field and laboratory studies. European Journal of Soil Biology, 2001. 37: p. 255-258.

79. Lakhani, K.H. and J.E. Satchell, Production by Lumbricus terrestris (L.). Journal of Animal Ecology, 1970. 39(2): p. 473-492.

80. Lavelle, P., Les vers de terre de la savane de Lamto (Côte d'Ivoire). Peuplements, populations et fonctions dans l'écosystème, 1978, Paris 6. p. 301.

81. Lavelle, P., L. Brussard, and P. Hendrix, Earthworm management in tropical agroecosystems1999, Wallingford: CABI Publishing. 300.

82. Lofs-Holmin, A., Measuring Growth of Earthworms as a Method of Testing Sublethal Toxicity of Pesticides. Swedish Journal of Agricultural Research, 1980. 10.

83. Lofs-Holmin, A., Reproduction and Growth of Common Arable Land and Pasture Species of Earthworms (Lumbricidae) in Laboratory Cultures. Swedish Journal of Agricultural Research, 1982. 13: p. 31-37.

84. Lowe, C. and K. Butt, Life-cycle traits of the dimorphic earthworm species Allolobophora chlorotica (Savigny, 1826) under controlled laboratory conditions. Biology and Fertility of Soils, 2007. 43(4): p. 495-499.

85. Lowe, C.N. and C.M. Bull, Influence of food particle size on inter-and intra-specific interactions of Allolobophora chlorotica (Savigny) and Lumbricus terrestris. Pedobiologia, 2003. 47: p. 574-577.

86. Lowe, C.N. and K.R. Butt, Interspecific interactions between earthworms: A laboratory-based investigation. Pedobiologia, 1999. 43: p. 808-817.

87. Lowe, C.N. and K.R. Butt, Growth of hatchling earthworms in the presence of adults: interactions in laboratory culture. Biology and Fertility of Soils, 2002. 35: p. 204-209.

88. Lowe, C.N. and K.R. Butt, Influence of organic matter on earthworm production and behaviour: a laboratory-based approach with applications for soil restoration. European Journal of Soil Biology, 2002. 38: p. 173-176.

89. Lowe, C.N. and K.R. Butt, Life cycle traits of the parthenogenetic earthworm Octolasion cyaneum (Savigny, 1826). European Journal of Soil Biology, 2008. 44(5-6): p. 541-544.

90. Maboeta, M.S., A.J. Reinecke, and S.A. Reinecke, The effects of low lead levels on the growth and reproduction of the African earthworm Eudrilus eugeniae (Oligochaeta). Biology and Fertility of Soils, 1999. 30(1): p. 113-116.

91. Maboeta, M.S., A.J. Reinecke, and S.A. Reinecke, Effects of Low Levels of Lead on Growth and Reproduction of the Asian Earthworm Perionyx excavatus (Oligochaeta). Ecotoxicology and Environmental Safety, 1999. 44(3): p. 236-240. 
92. Maleri, R., et al., Growth and Reproduction of Earthworms in Ultramafic Soils. Archives of Environmental Contamination and Toxicolology, 2007. 52: p. 363-370.

93. Manaf, L.A., et al., Influences of Bedding Material in Vermicomposting Process. International Journal of Biology, 2009. 1(1): p. 81-91.

94. McCredie, T.A., C.A. Parker, and I. Abbott, Population dynamics of the earthworm Aporrectodea trapezoides (Annelida: Lumbricidae) in a Western Australian pasture soil. Biology and Fertility of Soils, 1992. 12: p. 285-289.

95. Michon, J., Contribution expérimentale à l'étude de la Biologie des Lumbricidae. Les variations pondérales au cours des différentes modalités du développement postembryonnaire, 1954, Faculté des sciences de Poitiers: Poitiers. p. 192.

96. Monroy, F., et al., Life cycle of the earthworm Octodrilus complanatus (Oligochaeta, Lumbricidae). Comptes Rendus Biologies, 2007. 330: p. 389-391.

97. Mulder, C., R. Baerselman, and L. Posthuma, Empirical maximum lifespan of earthworms is twice that of mice. AGE, 2007. 29(4): p. 229-231.

98. Muñoz-Pedreros, A., et al., Aspectos de la biología reproductiva de lumbrícidos silvestres (Oligochaeta: Lumbricidae) en el sur de Chile. Revista Chilena de Historia Natural, 1997. 70: p. 101-108.

99. Muthukaruppan, G., S. Janardhanan, and G. Vijayalakshmi, Sublethal Toxicity of the Herbicide Butachlor on the Earthworm Perionyx sansibaricus and its Histological Changes (5 pp). Journal of Soils and Sediments, 2005. 5(2): p. 82-86.

100. Muyima, N.Y.O., A.J. Reinecke, and S.A. Viljoen-Reinecke, Moisture requirements of Dendrobaena veneta (oligochaeta), a candidate for vermicomposting. Soil Biology \& Biochemistry, 1994. 26(8): p. 973-976.

101. Nair, G.A. and S.A. Bennour, Cocoons and hatchlings of Aporrectodea caliginosa (Savigny 1826) (Oligochaeta: Lumbricidae) in Benghazi, Libya. Journal of Arid Environments, 1998. 40(4): p. 459-466.

102. Nakamura, Y., Growth of three species of earthworms (Lumbricidae) in laboratory cultures. Edaphologia, 1985. 34: p. 31-33.

103. Nath, S. and P.S. Chaudhuri, Growth and reproduction of Pontoscolex corethrurus (Muller) with different experimental diets. Tropical Ecology, 2014. 55(3): p. 305-312.

104. Neuhauser, E.F. and C.A. Callahan, Growth and reproduction of the earthworm Eisenia fetida exposed to sublethal concentrations of organic chemicals. Soil Biology \& Biochemistry, 1990. 22(2): p. 175-179.

105. Neuhauser, E.F., R. Hartenstein, and D.L. Kaplan, Growth of the earthworm Eisenia foetida in relation to population density and food rationing Oikos, 1980. 35: p. 93-98.

106. Neuhauser, E.F., D.L. Kaplan, and R. Hartenstein, Life history of the earthworm Eudrilus eugeniae. Revue d'Ecologie et de Biologie du Sol, 1979. 16(4): p. 525-534.

107. Neuhauser, E.F., et al., Materials supporting weight gain by the earthworm Eisenia foetida in waste conversion systems. Agricultural Wastes, 1980. 2: p. 43-60.

108. Neuhauser, E.F., R. Loehr, and M.R. Malecki, The potential of earthworms for managing sewage sludge, in Earthworms in waste and environmental management, C.A. Edwards, Editor 1988, SPB Academic Publishing: The Hague, The Netherlands. p. 9-20.

109. Neuhauser, E.F., et al., Dietary cobalt supplements and the growth and reproduction of the earthworm Eisenia foetida. Soil Biology \& Biochemistry, 1984. 16(5): p. 521-523.

110. Ortiz-Ceballos, A.I., et al., Influence of food quality, soil moisture and the earthworm Pontoscolex corethrurus on growth and reproduction of the tropical earthworm Balanteodrilus pearsei. Pedobiologia, 2005. 49(1): p. 89-98.

111. Padhan, A. and S.K. Sahu, Effect of rice mill wastewater on growth, reproduction and metabolism of Drawida willsi (oligochaeta) under laboratory conditions. International Journal of Research and Reviews in Applied Sciences, 2010. 5(1): p. 76-85. 
112. Panda, S. and S.K. Sahu, Effects of malathion on the growth and reproduction of Drawida willsi (Oligochaeta) under laboratory conditions. Soil Biology \& Biochemistry, 1999. 31: p. 363-366.

113. Parthasarathi, K., Life cycle of Lampito mauritii (Kinberg) in comparison with Eudrilus eugeniae (Kinberg) cultured on different substrates. Journal of Environmental Biology, 2007. 28(4): p. 803-812.

114. Perrson, T., L. Lenoir, and A. Taylor, Bioturbation in different ecosystems at Forsmark and Oskarshamn, 2007, Swedish Unversity of Agricultural Sciences. p. 34.

115. Phillipson, J. and P.J. Bolton, Growth and cocoon production by Allolobophora rosea (Oligochaeta: Lumbricidae). Pedobiologia, 1977. 17: p. 70-82.

116. Presley, M.L., T.C. McElroy, and W.J. Diehl, Soil moisture and temperature interact to affect growth, survivorship, fecundity, and fitness in the earthworm Eisenia fetida. Comparative Biochemistry and Physiology Part A: Physiology, 1996. 114(4): p. 319-326.

117. Reeh, U., Influence of population densities on growth and reproduction of the earthworm Eisenia andrei on pig manure. Soil Biology \& Biochemistry, 1992. 24(12): p. 1327-1331.

118. Reinecke, A.J. and L. Hallatt, Growth and cocoon production of Perionyx excavatus (Oligochaeta). Biology and Fertility of Soils, 1989. 8: p. 303-306.

119. Reinecke, A.J., M.S. Maboeta, and S.A. Reinecke, Stimulating effects of low lead concentrations on growth and cocoon production of Eisenia fetida (Oligochaeta). South African Journal of Zoology, 1997. 32(3): p. 72-75.

120. Reinecke, A.J. and S.A. Reinecke, Influence of worm density on growth and cocoon production of the asiatic earthworm Perionyx excavatus (Oligochaeta, Megascolecidae). European Journal of Soil Biology, 1994. 30(1): p. 29-33.

121. Reinecke, A.J. and S.A. Reinecke, The influence of heavy metals on the growth and reproduction of the compost worm Eisenia fetida (Oligochaeta). Pedobiologia, 1996. 40: p. 439-448.

122. Reinecke, A.J. and J.M. Venter, The influence of moisture on the growth and reproduction of the compost worm Eisenia fetida (Oligochaeta). Revue d'Ecologie et de Biologie du Sol, 1985. 22(4): p. 473-481.

123. Reinecke, A.J. and J.M. Venter, Moisture preferences, growth and reproduction of the compost worm Eisenia fetida (Oligochaeta). Biology and Fertility of Soils, 1987. 3: p. 135-141.

124. Reinecke, A.J. and S.A. Viljoen, The influence of feeding patterns on growth and reproduction of the vermicomposting earthworm Eisenia fetida (Oligochaeta). Biology and Fertility of Soils, 1990. 10(3): p. 184-187.

125. Reinecke, A.J. and S.A. Viljoen, A comparison of the biology of Eisenia fetida and Eisenia andrei (Oligochaeta). Biology and Fertility of Soils, 1991. 11(4): p. 295-300.

126. Reinecke, A.J., S.A. Viljoen, and R.J. Saayman, The suitability of Eudrilus eugeniae, Perionyx excavatus and Eisenia fetida (Oligochaeta) for vermicomposting in southern africa in terms of their temperature requirements. Soil Biology and Biochemistry, 1992. 24(12): p. 12951307.

127. Roobak Kumar, A., et al., Comparative Biology and composting ability of three Earthworm species. Journal of Biosciences Research, 2011. 2(1): p. 30-34.

128. Rozen, A., Effect of cadmium on life-history parameters in Dendrobaena octaedra (Lumbricidae: Oligochaeta) populations originating from forests differently polluted with heavy metals. Soil Biology \& Biochemistry, 2006. 38(3): p. 489-503.

129. Satchell, J.E., Chapter 9 - Lumbricidae, in Soil Biology, A. Burges and F. Raw, Editors. 1967, Academic Press. p. 259-322.

130. Shagoti, U.M., et al., Effect of temperature on growth and reproduction of the epigeic earthworm, Eudrilus eugeniae (Kinberg). Journal of Environmental Biology, 2001. 22(3): p. 213-217. 
131. Siddique, J., et al., Growth and Reproduction of Earthworm (Eisenia fetida) in Different Organic Media. Pakistan Journal of Zoology, 2005. 37(3): p. 211-214.

132. Springett, J.A. and J.A. Gray, Effect of repeated low doses of biocides on the earthworm Aporrectodea caliginosa in laboratory culture. Soil Biology \& Biochemistry, 1992. 24(12): p. 1739-1744.

133. Spurgeon, D.J. and S.P. Hopkin, Effects of Metal-Contaminated Soils on the Growth, Sexual Development, and Early Cocoon Production of the Earthworm Eisenia fetida, with Particular Reference to Zinc. Ecotoxicology and Environmental Safety, 1996. 35(1): p. 86-95.

134. Spurgeon, D.J. and S.P. Hopkin, Life-history patterns in reference and metal-exposed earthworm populations. Ecotoxicology, 1999. 8(2): p. 133-141.

135. Spurgeon, D.J., et al., Responses of earthworms (Lumbricus rubellus) to copper and cadmium as determined by measurement of juvenile traits in a specifically designed test system. Ecotoxicology and Environmental Safety, 2004. 57(1): p. 54-64.

136. Suthar, S., Growth and fecundity of earthworms: Perionyx excavatus and Perionyx sansibaricus in cattle waste solids. Environmentalist, 2009. 29: p. 78-84.

137. Suthar, S., Production of earthworm Allolobophora parva (Eisen) in cattle dung. Ecological Engineering, 2011. 37: p. 644-647.

138. Suthar, S. and S. Ram, Does substrate quality affect earthworm growth and reproduction patterns in vermicomposting systems? A study using three popular composting earthworms International Journal of Environment and Waste Management, 2008. 2(6): p. 584-600.

139. Svendsen, T.S. and G.H. Baker, Survival and growth of Aporrectodea longa (Lumbricidae) fed on sheep and cow dung with and without moxidectin residues. Australian Journal of Agricultural Research, 2002. 53(4): p. 447-451.

140. Tiunov, A.V. and S. Scheu, Carbon availability controls the growth of detritivores (Lumbricidae) and their effect on nitrogen mineralization. Oecologia, 2004. 138(1): p. 83-90.

141. Tondoh, E.J., Effect of coffee residues on growth and reproduction of Hyperiodrilus africanus (Oligochaeta, Eudrilidae) in Ivory Coast. Biology and Fertility of Soils, 1998. 26(4): p. 336-340.

142. Tondoh, E.J., Démographie et fonctionnement des populations du ver de terre Hyperiodrilus africanus (eudrilidiae) dans une savane protégée du feu en moyenne côte d'ivoire, 1998: Université Paris 6. p. 92.

143. Tondoh, E.J. and P. Lavelle, Effect of two organic residues on growth and cocoon production of the earthworm Hyperiodrilus africanus (Eudrilidae). European Journal of Soil Biology, 1997. 33(1): p. 13-18.

144. Tripathi, G. and P. Bhardwaj, Comparative studies on biomass production, life cycles and composting efficiency of Eisenia fetida (Savigny) and Lampito mauritii (Kinberg). Bioresource Technology, 2004. 92(3): p. 275-283.

145. Tsukamoto, J. and $\mathrm{H}$. Watanabe, Influence of temperature on hatchling and growth of Eisenia foetida (Oligochaeta, Lumbricidae). Pedobiologia, 1977. 17: p. 338-342.

146. Valle, J.V., et al., Growth in the laboratory of Hormogaster elisae (Oligochaeta, Hormogastridae). Applied Soil Ecology, 1998. 9: p. 111-114.

147. Valle, J.V., et al., Annual Study of a Population of Hormogaster elisae (Oligochaeta, Hormogasteridae). na, na.

148. van Gestel, C.A.M., et al., Influence of cadmium, copper, and pentachlorophenol on growth and sexual development of Eisenia andrei (Oligochaeta; Annelida). Biology and Fertility of Soils, 1991. 12(2): p. 117:121.

149. Venter, J.M. and A.J. Reinecke, Dieldrin and growth and development of the earthworm, Eisenia fetida (Oligochaeta). Bulletin of Environmental Contamination and Toxicology, 1985. 35(1): p. 652-659.

150. Venter, J.M. and A.J. Reinecke, The life-cycle of the compost worm Eisenia fetida (Oligochaeta). South African Journal of Zoology, 1988. 23(3): p. 161-165. 
151. Venter, J.M. and A.J. Reinecke, Sublethal ecotixocological effects of dieldrin on the earthworm Eisenia foetida (Oligochaeta), in Earthworms in waste and environmental management, C.A. Edwards, Editor 1988, SPB Academic Publishing: The Hague, The Netherlands. p. 337-353.

152. Vercesi, M.L., P.H. Krogh, and M. Holmstrup, Can Bacillus thuringiensis (Bt) corn residues and Bt-corn plants affect life-history traits in the earthworm Aporrectodea caliginosa? Applied Soil Ecology, 2006. 32: p. 180-187.

153. Vermeulen, L.A., A.J. Reinecke, and S.A. Reinecke, Evaluation of the Fungicide ManganeseZinc Ethylene Bis(dithiocarbamate) (Mancozeb) for Sublethal and Acute Toxicity to Eisenia fetida (Oligochaeta). Ecotoxicology and Environmental Safety, 2001. 48(2): p. 183-189.

154. Viljoen, S.A. and A.J. Reinecke, The number, size and growth of hatchlings of the African nightcrawler, Eudrilus eugeniae (Oligochaeta). Revue d'Ecologie et de Biologie du Sol, 1988. 25(2): p. 225-236.

155. Viljoen, S.A. and A.J. Reinecke, Moisture and growth, maturation and cocoon production of Eudrilus eugeniae (Oligochaeta). Revue d'Ecologie et de Biologie du Sol, 1989. 26(3): p. 291303.

156. Viljoen, S.A. and A.J. Reinecke, Life-cycle of the African nightcrawler, Eudrilus eugeniae (Oligochaeta). South African Journal of Zoology, 1989. 24(1): p. 27-32.

157. Viljoen, S.A. and A.J. Reinecke, The temperature requirements of the epigeic earthworm species Eudrilus eugeniae (oligochaeta) - a laboratory study. Soil Biology and Biochemistry, 1992. 24(12): p. 1345-1350.

158. Viljoen, S.A., A.J. Reinecke, and L. Hartman, Life-cycle of the European compost worm Dendrobaena veneta (Oligochaeta). South African Journal of Zoology, 1991. 26(1): p. 43-48.

159. Viljoen, S.A., A.J. Reinecke, and L. Hartman, The influence of temperature on the life-cycle of Dendrobaena veneta (Oligochaeta). Soil Biology \& Biochemistry, 1992. 24(12): p. 1341-1344.

160. Vorsters, A., F. Demey, and J. Hardouin, Influence of Worm Density on the Growth Eudrilus eugeniae. Tropicultura, 1997. 15(2): p. 89-90.

161. West, H.K., et al., Evidence for interpopulation differences in life history parameters of Lumbricus rubellus. Pedobiologia, 2003. 47: p. 535-541.

162. Widarto, T.H., M. Holmstrup, and V.E. Forbes, The influence of nonylphenol on life-history of the earthworm Dendrobaena octaedra Savigny: linking effects from the individual- to the population-level. Ecotoxicology and Environmental Safety, 2004. 58(2): p. 147-159. 


\section{b) Publications in which data were searched to build the EGrowth database, but from which NO data were included in the EGrowth}

1. Abbasi, S.A. and R. Soni, Stress-induced enhancement of reproduction in earthworm Octochaetus pattoni exposed to chromium (VI) and mercury (II) - implications in environmental management. Journal of Environmental Studies, 1983. 22: p. 43-47.

2. Addison, J.A. and S.B. Holmes, Comparison of Forest Soil Microcosm and Acute Toxicity Studies for Determining Effects of Fenitrothion on Earthworms. Ecotoxicology and Environmental Safety, 1995. 30: p. 127-133.

3. Adell, J.C. and J.L. Mensua, Study of quantitative characters in the earthworm Eisenia fetida (Oligochaeta, Lumbricidae). Revue d'écologie et de biologie du sol, 1989. 26(4): p. 439-449.

4. Al-yousuf, S. and A. Shoreit, Effects of earthworm Aporrectodea caliginosa on some factors in different soil cultures. Zoologischer Anzeiger, 1992. 228(5-6): p. 201-211.

5. Bain, S.O., K.R. Butt, and R.M. Morris, Survival and reproduction of Lumbricus terrestris L. in colliery spoil and sewage sludge. Pedobiologia, 1999. 43: p. 729-734.

6. Baker, G.H., Distribution, abundance and species associations of earthworms (Lumbricidae) in a reclaimed peat soil in Ireland. Holartic Ecology, 1983. 6: p. 74-80.

7. Baker, G.H. and W.A. Whitby, Soil pH preferences and the influences of soil type and temperature on the survival and growth of Aporrectodea longa (Lumbricidae): The 7th international symposium on earthworm ecology $\cdot$ Cardiff $\cdot$ Wales $\cdot$ 2002. Pedobiologia, 2003. 47(5-6): p. 745-753.

8. Barne, A.Z. and B.R. Striganova, Evaluation of Production Parameters of Earthworms Eiseniella tetraedra Sav. in a Laboratory Culture. Biology Bulletin, 2005. 32(3): p. 264-267.

9. Barois, I., et al., Ecology of earthworm species with large environmental tolerance and/or extended distributions, in Earthworm management in tropical agroecosystems, P. Lavelle, L. Brussaard, and P. Hendrix, Editors. 1999, CABI: Wallingford. p. 57-85.

10. Baveco, J.M. and A.M. De Roos, Assessing the impact of pesticides on lumbricid populations: an individual-based modelling approach. Journal of Applied Ecology, 1996. 33: p. 1451-1468.

11. Bhadauria, T. and P.S. Ramakrishnan, Earthworm population dynamics and contribution to nutrient cycling during cropping and fallow phases of shifting agriculture (Jhum) in northeast India. Journal of Applied Ecology, 1989. 26: p. 505-520.

12. Bhadauria, T., P.S. Ramakrishnan, and K.N. Srivastava, Population dynamics of earthworms during crop rotation under rainfed agriculture in central Himalayas, India. Applied Soil Ecology, 1997. 6(3): p. 205-215.

13. Bhattacharjee, G. and P.S. Chaudhuri, Cocoon production, morphology, hatchling pattern and fecundity in seven tropical earthworm species - a laboratory-based investigation. Journal of Biosciences, 2002. 27: p. 283-294.

14. Biradar, V.A., et al., Seasonal variations in growth and reproduction of the earthworm Perionyx excavatus (Oligochaeta: Megascolecidae). Biology and Fertility of Soils, 1999. 28(4): p. 389-392.

15. Bisht, R., et al., Population dynamics of earthworms (Oligochaeta) in cultivated soils of central Himalayan tarai region. Tropical Ecology, 2003. 44((2): p. 229-234.

16. Booth, L.H., V.J. Heppelthwaite, and K. O'Halloran, Growth, development and fecundity of the earthworm Aporrectodea caliginosa after exposure to two organophosphates. New Zealand Plant Protection, 2000. 53: p. 221-225.

17. Boström, U., Growth and cocoon production by the earthworm Aporrectodea caliginosa in soil mixed with various plant materials. Pedobiologia, 1988. 32: p. 77-80.

18. Boström, U. and A. Lofs, Annual population dynamics of earthworms and cocoon production by Aporrectodea caliginosa in a meadow fescue ley. Pedobiologia, 1996. 40: p. 32-42. 
19. Brown, P.J., et al., Toxicological and biochemical responses of the earthworm Lumbricus rubellus to pyrene, a non-carcinogenic polycyclic aromatic hydrocarbon. Chemosphere, 2004. 57(11): p. 1675-1681.

20. Buch, A.C., Pontoscolex corethrurus (Müller, 1857) e Eisenia andrei, Bouché 1972, como bioindicadoras de solos contaminados por agrotoxicos, 2010, Universidade Federal do Parana: Curitiba. p. 60.

21. Buckerfield, J.C., Earthworm populations in dryland cropping soils under conservation-tillage in South Australia. Soil Biology \& Biochemistry, 1992. 24(12): p. 1667-1672.

22. Butt, K.R., Depth of cocoon deposition by three earthworm species in mesocosms. European Journal of Soil Biology, 2002. 38(2): p. 151-153.

23. Butt, K.R., J. Frederickson, and R.M. Morris, The earthworm inoculation unit technique: an integrated system for cultivation and soil-inoculation of earthworms. Soil biology \& Biochemistry, 1997. 29(3/4): p. 251-257.

24. Butt, K.R. and V. Nuutinen, Reproduction of the earthworm Lumbricus terrestris Linné after the first mating. Can. J. Zool., 1998. 76: p. 104-109.

25. Butt, K.R., et al., Long-term trends in earthworm populations of cropped experimental watersheds in Ohio, USA. Pedobiologia, 1999. 43: p. 713-719.

26. Byzov, B.A., L.M. Poljanskaja, and V.N. Tan, The role of yeasts as growth stimulators for Eisenia fetida in vermicomposting systems. Acta Zoologica Fennica, 1995. 196: p. 376-379.

27. Chakrabarty, D., S.K. Das, and M.K. Das, Earthworm (Eudrillus eugeniae) multiplication through variable substrates. Aquaculture Nutrition, 2009. 15: p. 513-516.

28. Chaudhuri, P.S. and S. Bhattacharjee, Capacity of various experimental diets to support biomass and reproductin of Perionyx excavatus. Bioresource Technology, 2002. 82: p. 147150.

29. Chaudhuri, P.S. and S. Bhattacharjee, Reproductive biology of eight tropical earthworm species of rubber plantations in Tripura, India. Tropical Ecology, 2011. 52(1): p. 49-60.

30. Chauhan, H.K. and K. Singh, Effect of Binary Combinations of Buffalo, Cow and Goat Dung with Different Agro Wastes on Reproduction and Development of Earthworm Eisenia fetida (Haplotoxida: Lumbricidae). World Journal of Zoology, 2012. 7(1): p. 23-29.

31. Chauhan, T.P.S., Seasonal changes in the activities of some tropical earthworms. Comparative Physiology and Ecology, 1980. 5(4): p. 288-289.

32. Choo, L.P.D. and G.H. Baker, Influence of four commonly used pesticides on the survival, growth, and reproduction of the earthworm Aporrectodea trapezoides (Lumbricidae). Australian Journal of Agricultural Research, 1998. 49(8): p. 1297-1303.

33. Christensen, O. and J.G. Mather, Dynamics of lumbricid earthworm cocoons in relation to habitat conditions at three different arable sites. Pedobiologia, 1990. 34: p. 227-238.

34. Csudi, C. and A. Zisci, Weitere Angaben zur Lebensweise von Dendrobaena hortensis (Michaelsen, 1890) (Oligochaeta: Lumbricidae). Opuscula Zoologica Budapest, 1988. 23: p. 141-147.

35. Curry, J.P. and T. Bolger, Growth, reproduction and litter and soil consumption by Lumbricus terrestris L. in reclaimed peat. Soil Biology \& Biochemistry, 1984. 16(3): p. 253-257.

36. Dalby, P.R., G.H. Baker, and S.E. Smith, Competition and cocoon consumption by the earthworm Aporrectodea longa. Applied Soil Ecology, 1998. 10(1-2): p. 127-136.

37. Daniel, O., Life cycle and population dynamics of the earthworm Lumbricus terrestris 1990, Swiss Federal Insitute of Technology Zurich: Zurich. p. 77.

38. Daniel, O., Population dynamics of Lumbricus terrestris L. (Oligochaeta: Lumbricidae) in a meadow. Soil Biology \& Biochemistry, 1992. 24(12): p. 1425-1431.

39. Daniel, O., Reproduction by the earthworm Lumbricus terrestris L. (Oligochaeta, Lumbricidae). Acta Zoologica Fennica, 1995. 196: p. 215-218.

40. Dash, M.C. and B.K. Senapati, Cocoon morphology, hatchling and emergence pattern in tropical earthworms Pedobiologia, 1980. 20: p. 316-324. 
41. Dash, M.C. and B.K. Senapati, Environmental regulation of oligochaete reproduction in tropical pastures. Pedobiologia, 1982. 23: p. 270-271.

42. Diaz Cosin, D.J., et al., Algunos aspectos del ciclo biológico del endemismo ibérico, Hormogaster elisae Alvarez, 1977 (Oligochaeta, Hormogastridae), en cultivos de laboratorio. Bol. R. Soc. Esp. Hist. Nat. Sec. Biol., 2009. 103: p. 49-56.

43. Dominguez, J., et al., Uniparental reproduction of Eisenia fetida and E. andrei (Oligochaeta: Lumbricidae): evidence of self-insemination. Pedobiologia, 2003. 47(5-6): p. 530-534.

44. Dominguez, J., A. Velando, and A. Ferreiro, Are Eisenia fetida (Savigny, 1826) and Eisenia andrei Bouché (1972) (Oligochaeta, Lumbricidae) different biological species? Pedobiologia, 2005. 49: p. 81-87.

45. Doube, D.M. and L. Auhl, Over-summering of cocoons of the earthworm Microscolex dubius (Megascolicidae) in a hot dry Mediterranean environment. Pedobiologia, 1998. 42: p. 71-77.

46. Edwards, C.A., J. Dominguez, and E.F. Neuhauser, Growth and reproduction of Perionyx excavatus (Perr.) (Megascolecidae) as factors in organic waste management. Biology and Fertility of Soils, 1998. 27: p. 155-161.

47. Eggleton, P., et al., A six year study of earthworm (Lumbricidae) populations in pasture woodland in southern England shows their responses to soil temperature and soil moisture. Soil Biology \& Biochemistry, 2009. 41: p. 1857-1865.

48. El Badawy, M., A. Kenawy, and A.F. El-Aswad, Toxicity Assessment of Buprofezin, Lufenuron, and Triflumuron to the Earthworm Aporrectodea caliginosa. International Journal of Zoology, 2013. 2013: p. 1-9.

49. Elvira, C., L. Sampedro, and R. Nogales, Suitability of sludges from dairy and paper industries for growth and reproduction of Eisenia andrei. Pedobiologia, 1999. 43: p. 766-770.

50. Emmerling, C., et al., Cultivation of transgenic cyanophycin-producing potatoes does not negatively affect growth, reproduction and activity of the earthworm Lumbricus terrestris (L.). Pedobiologia, 2012. 55: p. 161-165.

51. Eriksen-Hamel, N.S., et al., Earthworm populations and growth rates related to long-term crop residue and tillage management. Soil \& Tillage Research, 2009. 104: p. 311-316.

52. Eriksen-Hamel, N.S. and J.K. Whalen, Growth rates of Aporrectodea caliginosa (Oligochaetae: Lumbricidae) as influenced by soil temperature and moisture in disturbed and undisturbed soil columns. Pedobiologia, 2006. 50: p. 207-215.

53. Eriksen-Hamel, N.S. and J.K. Whalen, Competitive interactions affect the growth of Aporrectodea caliginosa and Lumbricus terrestris (Oligochaeta: Lumbricidae) in single-and mixed-species laboratory cultures. European Journal of Soil Biology, 2007. 43: p. 142-150.

54. Eriksen-Hamel, N.S. and J.K. Whalen, The "deduction" approach: A non-invasive method for estimating secondary production of earthworm communities. Acta Oecologia, 2009. 35: p. 477-484.

55. Evans, A.C. and W.J.M. Guild, LIX.-Some notes on reproduction in British earthworms. Annals and Magazine of Natural History, 1947. 14(117): p. 654-659.

56. Evans, A.C. and W.J.M. Guild, Studies on the relationships between earthworms and soil fertility. V. Fields populations Annals of Applied Biology, 1948. 35(4): p. 485-493.

57. Evans, A.C. and W.J.M. Guild, Studies on the relationships between earthworms and soil fertility. IV. On the life cycles of some british Lumbricidae. Annals of Applied Biology, 1948. 35(4): p. 471-484.

58. Farrukh, S. and A.S. Ali, Effects of Dichlorovos Organophosphate on Growth, Reproduction, and Avoidance Behavior of Earthworm Eisenia foetida. Iranian Journal of Toxicology, 2011. 5(14): p. 495-501.

59. Fayolle, L., Valeur des ordures ménagères comme milieu d'élevage pour Eisenia fetida andrei (Oligochaeta: Lumbricidae). Revue d'Ecologie et de Biologie du Sol, 1985. 22(3): p. 353-366.

60. Ferreira, R.C., S. Papini, and M.M. de Andrea, Bioavailability and influence of ${ }^{14} \mathrm{C}$-carbofuran on Eisenia andrei avoidance, growth and reproduction in treated natural tropical soils. 
Journal of environmental science and health. Part. B, Pesticides, food contaminants, and agricultural wastes, 2015. 50(4): p. 266-74.

61. Field, S.G., J.S. Hendrick, and N.K. Michiels, The influence of Monocystis sp. infection on growth and mating behaviour of the earthworm Lumbricus terrestris. Canadian Journal of Zoology, 2003. 81: p. 1161-1167.

62. Field, S.G. and N.K. Michiels, Parasitism and growth in the earthworm Lumbricus terrestris: fitness costs of the gregarine parasite Monocystis sp. Parasitology, 2005. 130: p. 397-403.

63. Fischer, E. and L. Koszorus, Sublethal effects, accumulation capacities and elimination rates of $\mathrm{As}, \mathrm{Hg}$, and Se in the manure worm, Eisenia fetida (Oligochaeta, Lumbricidae).

Pedobiologia, 1992. 36: p. 172-178.

64. Foot, K. and E.C. Strobell, Further Notes on the Cocoons of Allolobophora foetida. Biological Bulletin, 1902. 3(5): p. 206-213.

65. Freckman, D.F., et al., Linking Biodiversity and Ecosystem Functioning of Soils and Sediments. Ambio, 1997. 26(8): p. 556-562.

66. Frederickson, J. and G. Howell, Large-scale vermicomposting: emission of nitrous oxide and effects of temperature on earthworm populations: The 7th international symposium on earthworm ecology · Cardiff · Wales · 2002. Pedobiologia, 2003. 47(5-6): p. 724-730.

67. Garvin, M.H., et al., Interactions of Hormogaster elisae (Oligochaeta, Hormogastride) with other earthworm species from Redueña (Madrid, Spain). Applied Soil Ecology, 2002. 20: p. 163-169.

68. Garvin, M.H., D. Trigo, and D.J. Diaz Cosin, Some data on the reproductive biology of Hormogaster elisae Alvarez, 1977 (Oligochaeta, Hormogastridae). Pedobiologia, 1999. 43: p. 830-834.

69. Garvin, M.H., et al., Gametogenesis and Reproduction in Hormogaster elisae (Oligochaeta, Hormogastridae). Invertebrate Biology, 2003. 122(2): p. 152-157.

70. Gordo, P.H., Estudio de la distribucion horizontal de "Hormogaster elisae" (Oligochaeta, Hormogastridae) en el molar y de los factores que le regulan, in Facultad de ciencias biologicas2006, Universidad complutense de Madrid: Madrid. p. 254.

71. Graff, O., Die Regenwürmer Deutschlands1953, Hannover: Verlag. 81.

72. Grigoropoulou, N., K.R. Butt, and C.N. Lowe, Effects of adult Lumbricus terrestris on cocoons and hatchlings in Evans' boxes. Pedobiologia, 2008. 51: p. 343-349.

73. Gunn, A. and J.W. Sadd, The effect of ivermectin on the survival, behaviour and cocoon production of the earthworm Eisenia fetida. Pedobiologia, 1994. 38: p. 327-333.

74. Haimi, J., Growth and reproduction of the compost-living earthworms Eisenia andrei and E. fetida. Revue d'Ecologie et de Biologie du Sol, 1990. 24(4): p. 415-421.

75. Hallatt, L., A.J. Reinecke, and S.A. Viljoen, Life cycle of the oriental compost Perionyx excavatus (Oligochaeta). South African Journal of Zoology, 1990. 35(1): p. 41-45.

76. Hand, P., et al., Vermicomposting of cow slurry. Pedobiologia, 1988. 31: p. 199-209.

77. Hartenstein, R., Production of Earthworms as a Potentially Economical Source of Protein. Biotechnology and Bioengineering, 1981. 23(8): p. 1797-1811.

78. Hartenstein, R. and L. Amico, Production and carrying capacity for eathworm Lumbricus terrestris in culture. Soil Biology \& Biochemistry, 1983. 15(1): p. 51-54.

79. Hartenstein, R., E.F. Neuhauser, and D.L. Kaplan, Reproductive Potential of the Earthworm Eisenia foetida. Oecologia, 1979. 43(3): p. 329-340.

80. Haukka, J.K., Growth and survival of Eisenia fetida (Sav.) (Oligochaeta: Lumbricidae) in relation to temperature, moisture and presence of Enchytraeus albidus (Henle) (Enchytraeidae). Biology and Fertility of Soils, 1987. 3: p. 99-102.

81. Heggelund, L.R., et al., Soil pH effects on the comparative toxicity of dissolved zinc, non-nano and nano ZnO to the earthworm Eisenia fetida. Nanotoxicology, 2014. 8(5): p. 559-572. 
82. Hendrix, P.F., et al., Abundance and distribution of earthworms in relation to landscape factors on the Georgia Piedmont, USA. Soil Biology \& Biochemistry, 1992. 24(12): p. 13571361.

83. Herrera, J.A.D. and C.C. de Mischis, Influence of feeding in the biological cycle of Eisenia foetida (Savigny) (Annelida, Oligochaeta, Lumbricidae). Megadrilogica, 1994. 5(11): p. 117124.

84. Holmstrup, M., Physiology of cold hardiness in cocoons of five earthworm taxa (Lumbricidae: Oligochaeta). Journal of Comparative Physiology B, 1994. 164(3): p. 222-228.

85. Holmstrup, M., Cocoon production of Aporrectodea longa Ude and Aporrectodea rosea Savigny (Oligochaeta; Lumbricidae) in a Danish grass field. Soil Biology \& Biochemistry, 1999. 31: p. 957-964.

86. Holmstrup, M., Field assessment of toxic effects on reproduction in the earthworms Aporrectodea longa and Aporrectodea rosea. Environmental Toxicology and Chemistry, 2000. 19(7): p. 1781-1787.

87. Holmstrup, M., Sensitivity of life history parameters in the earthworm Aporrectodea caliginosa to small changes in soil water potential. Soil Biology \& Biochemistry, 2001. 33(9): p. 1217-1223.

88. Holmstrup, M., et al., The relationship between temperature and cocoon incubation time for some Lumbricid earthworm species Pedobiologia, 1991. 35: p. 179-184.

89. Holmstrup, M., et al., Note on the incubation of earthworm cocoons at three constant temperatures. Pedobiologia, 1996. 40: p. 477-478.

90. Holmstrup, M. and V. Simonsen, Genetic and physological differences between two morphs of the Lumbricid earthworm Dendrodrilus rubidus (Savigny, 1826). Soil Biology \& Biochemistry, 1996. 28(8): p. 1105-1107.

91. Hou, J., et al., The Influence of Temperature, $\mathrm{pH}$ and $\mathrm{C} / \mathrm{N}$ Ratio on the Growth and Survival of Earthworms in Municipal Solid Waste. International Commission of Agricultural Engineering (CIGR), 2005. 7: p. 1-6.

92. Huerta, E., et al., Enhancement of growth and reproduction of the tropical earthworm Polypheretima elongata (Megascolecidae) by addition of Zea mays and Mucuna pruriens var. utilis litter to the soil. European Journal of Soil Biology, 2005. 41(1-2): p. 45-53.

93. Hughes, M.S., C.M. Bull, and B.M. Doube, The effects of sheep manure on the survival and growth of the earthworm Microscolex dubius (Annelida: Acanthodrilidae). Applied Soil Ecology, 1994. 1(4): p. 291-298.

94. Inouye, L.S., R.P. Jones, and A.J. Bednar, Tungsten effects on survival, growth, and reproduction in the earthworm Eisenia fetida. Environmental Toxicology and Chemistry 2006. 25(3): p. 763-768.

95. Jager, T., S.A. Reinecke, and A.J. Reinecke, Using process-based modelling to analyse earthworm life cycles. Soil Biology \& Biochemistry, 2006. 38: p. 1-6.

96. James, S.W., Seasonal and experimental variation in population structure of earthworms in tallgrass prairie. Soil Biology \& Biochemistry, 1992. 24(12): p. 1445-1449.

97. Jefferies, I.R. and E. Audsley, A population model for the earthworm Eisenia foetida, in Earthworms in waste and environmental management, C.A. Edwards, Editor 1988, SPB Publishing: The Hague, The Netherlands. p. 119-134.

98. Jensen, K.S. and M. Holmstrup, Estimation of earthworm cocoon development time and its use in studies of in situ reproduction rates. Applied Soil Ecology, 1997. 7(1): p. 73-82.

99. Jeshika, M., Effect of paper waste on the life cycle of earthworm Eudrilus eugeniae (Kinberg). Scrutiny International Research Journal of Biological and Environmental Science, 2014. 1(1): p. 7-12.

100. Jimenez, J.J., Estructura de las comunidades y dinamica de las poblaciones de lombrices de tierra en las sabanas naturales y perturbadas de carimagua (Colombia), 1999, Universidad complutense de Madrid. p. 296. 
101. Jiménez, J.J., Earthworm communities in native savannas and man-made pastures of the Eastern Plains of Colombia. Biology and Fertility of Soils, 1998. 28: p. 101-110.

102. Jimenez, J.J. and T. Decaëns, The impact of soil organisms on soil functioning under neotropical pastures: a case study of a tropical anecic earthworm species. Agriculture Ecosystems \& Environment, 2004. 103: p. 329-342.

103. Jiménez, J.J., A.G. Moreno, and P. Lavelle, Reproductive strategies of three natives earthworm species from the savannas of Carimagua (Columbia). Pedobiologia, 1999. 43: p. 851-858.

104. Johnson-Maynard, J.L., K.J. Umiker, and S.O. Guy, Earthworm dynamics and soil physical properties in the first three years of no-till management. Soil and Tillage Research, 2007. 94(2): p. 338-345.

105. Joshi, N. and M. Dabral, Life cycle of earthworms Drawida nepalensis, Metaphire houlleti and Perionyx excavatus under laboratory controlled conditions. Life Science Journal, 2008. 5(4): p. 83-86.

106. Jun, T., et al., Maize residue application reduces negative effects of soil salinity on the growth and reproduction of the earthworm Aporrectodea trapezoides, in a soil mesocosm experiment. Soil Biology \& Biochemistry, 2012. 49: p. 46-51.

107. Kale, R.D., K. Bano, and R.V. Krishnamoorthy, Potential of Perionyx excavatus for utilizing organic wastes. Pedobiologia, 1982. 23: p. 419-425.

108. Kammenga, J.E., et al., Explaining density-dependent regulation in earthworm populations using life-history analysis. Oikos, 2003. 100: p. 89-95.

109. Kaushal, B.R. and S.P.S. Bisht, Population dynamics of the earthworm Amynthas alexandri (Annelida: Megascolecidae) in a Kumaun Himalayan pasture soil. Biology and Fertility of Soils, 1994. 17: p. 9:13.

110. Kaushal, B.R., S.P.S. Bisht, and S. Kalia, Population dynamics of the earthworm Amynthas alexandri (Megascolecidae: Annelida) in cultivated soils of the Kumaun Himalayas. Applied Soil Ecology, 1995. 2: p. 125-130.

111. Kaushik, P. and V.K. Garg, Vermicomposting of mixed solid textile mill sludge and cow dung with the epigeic earthworm Eisenia foetida. Bioresource Technology, 2003. 90(3): p. 311316.

112. Khalil, M.A., et al., Effects of metals and metal mixtures on survival and cocoon production of the earthworm Aporrectodea caliginosa. Pedobiologia, 1996. 40: p. 548-556.

113. Khomami, M.A., et al., Growth and reproductive performance of Eisenia foetida in cow manure, cow manure + sugarcane bagasse, and cow manure + sawdust waste. Applied Ecology and Environmental Research, 2016. 14(1): p. 237-247.

114. Klok, C. and A.M. de Roos, Population Level Consequences of Toxicological Influences on Individual Growth and Reproduction in Lumbricus rubellus (Lumbricidae, Oligochaeta). Ecotoxicology and Environmental Safety, 1996. 33(2): p. 118-127.

115. Klok, C. and J. Thissen, Are laboratory derived toxicity results informative for field situations? Case study on earthworm populations contaminated with heavy metals. Soil Biology \& Biochemistry, 2009. 41: p. 251-255.

116. Klok, C., et al., Does reproductive plasticity in Lumbricus rubellus improve the recovery of populations in frequently inundated river floodplains? Soil Biology \& Biochemistry, 2006. 38 : p. 611-618.

117. Korschelt, E., Über Transplantationsversuche, Ruhezustände und Lebensdauer der Lumbriciden. Zoologischer Anzeiger, 1913. XLIII(12): p. 537-555.

118. Kostecka, J., Usefulness of flax seeds in Eisenia fetida (Sav.) earthworm breeding. Pedobiologia, 1999. 43: p. 776-781.

119. Kretzschmar, A. and C. Bruchou, Weight response to the soil water potential of the earthworm Aporrectodea longa. Biology and Fertility of Soils, 1991. 12: p. 209-212. 
120. Kula, H., Comparison of laboratory and field testing for the assessment of side effects on earthworms. Acta Zoologica Fennica, 1995. 196: p. 338-341.

121. Kula, H. and C. Kokta, Side effecs of selected pesticides on earthworms under laboratory and field conditions. Soil Biology \& Biochemistry, 1992. 24(12): p. 1711-1714.

122. Landrum, M., et al., Effects of perchlorate on earthworm (Eisenia fetida) survival and reproductive success. Science of the Total Environment, 2006. 363(1-3): p. 237-244.

123. Lavelle, P., Relations entre types écologiques et profils démographiques chez les vers de terre de la savanne de Lamto (Côte d'Ivoire). Revue d'Ecologie et de Biologie du Sol, 1979. 16(1): p. 85-101.

124. Lavelle, P., et al., Adaptive strategies of Pontoscolex corethrurus (Glossoscolecidae, Oligochaeta), a peregrine geophagous earthworm of the humid tropics. Biology and Fertility of Soils, 1987. 5(3): p. 188-194.

125. Lavelle, P., L. Brussard, and P. Hendrix, Earthworm management in tropical agroecosystems1999, Wallingford: CABI Publishing. 300.

126. Leduc, F., J.K. Whalen, and G.I. Sunahara, Growth and reproduction of the earthworm Eisenia fetida after exposure to leachate from wood preservatives. Ecotoxicology and Environmental Safety, 2008. 69: p. 219-226.

127. Lekshemanasamy, J.M.M., Reproductive performance of Eudrilus eugeniae (Kingberg) in Pongamia pinnata Leaf Medium. Online International Interdisciplinary Research Journal, 2012. 2(6): p. 2-8.

128. Levira, C., Characterization of cocoons and hatchlings from earthworm species (Oligochaeta, Lumbricidae). Boletin de la Real Sociedad Espanola de Historia Natural, Seccion Biologica, 1998. 94(1/2): p. 33-38.

129. Lofs-Holmin, A., Measuring cocoon production of the earthworm Allolobophora-caliginosa (sav) as a method of testing sublethal toxicity of pesticides - an experiment with benomyl. Swedish journal of agricultural research, 1982. 12(3): p. 117-119.

130. Loh, T.C., et al., Vermicomposting of cattle and goat manures by Eisenia foetida and their growth and reproduction performance. Bioresource Technology, 2005. 96(1): p. 111-114.

131. Lowe, C.N. and K.R. Butt, Culture of commercially obtained Lumbricus terrestris L.: Implications for sub-lethal ecotoxicological testing. Soil Biology \& Biochemistry, 2007. 39: p. 1674-1679.

132. Ma, W.-c., Sublethal toxic effects of copper on growth, reproduction and litter breakdown activity in the earthworm Lumbricus rubellus, with observations on the influence of temperature and soil $\mathrm{pH}$. Environmental Pollution Series A, Ecological and Biological, 1984. 33(3): p. 207-219.

133. Malecki, M.R., E.F. Neuhauser, and R. Loehr, The effect of metals on the growth and reproduction of Eisenia fetida (Oligochaeta, Lumbricidae). Pedobiologia, 1982. 24: p. 129137.

134. Manna, M.C., et al., Growth and reproduction of the vermicomposting earthworm Perionyx excavatus as influenced by food materials. Biology and Fertility of Soils, 1997. 24(1): p. 129132.

135. Marinissen, J.C.Y., Population dynamics of earthworms in a silt loam soil under conventional and "integrated" arable farming during two years with different weather patterns. Soil Biology \& Biochemistry, 1992. 24(12): p. 1647-1654.

136. Martin, N.A. Earthworms in New Zealand agriculture. in 31st New Zealand Weed and Pest Control Conference. 1978. New Zealand.

137. Mazantseva, G.P., Growth patterns in the earthworm Nicodrilus caliginosus (Oligochaeta: Lumbricidae) during the first year of life. Pedobiologia, 1982. 23: p. 272-276.

138. Mba, C.C., Influence of different mulch treatments on growth rate and activity of the earthworm Eudrilus eugeniae (Kinberg). Zeitschrift für Pflanzenernährung und Bodenkunde, 1978. 141(4): p. 453-468. 
139. Mba, C.C., The effects of diet and incubating media on the production and hatchability of Eudrilus eugeniae (Kinberg) cocoons, in On earthworms, A.M. Bonvivicini and P. Omodeo, Editors. 1987: Mucchi, Modena. p. 215-224.

140. McLean, M.A., D.U. Kolodka, and D. Parkinson, Survival and growth of Dendrobaena octaedra (Savigny) in pine forest floor materials. Pedobiologia, 1996. 40: p. 281-288.

141. Meyer, W.J. and H. Bouwman, Suitable characters for selective breeding in Eisenia fetida (Oligochaeta). Biology and Fertility of Soils, 1995. 20: p. 53-56.

142. Meyer, W.J. and H. Bouwman, Anisopary in compost earthworm reproductive strategies (Oligochaeta). Soil Biology \& Biochemistry, 1997. 29(3/4): p. 731-735.

143. Miles, H.B., Heat-death Temperature in Allolobophora terrestris (Sav.) forma longa (Ude) and eisenia foetida (Sav.). Nature, 1963. 199: p. 826.

144. Mohamed, A.I., et al., Impacts of pesticides on the survival and body mass of the earthworm Apporectodea caliginosa (Annelida: Oligochaeta). Acta Zoologica Fennica, 1995. 196: p. 344347.

145. Monroy, F., et al., Seasonal population dynamics of Eisenia fetida (Savigny, 1826) (Oligochaeta, Lumbricidae) in the field. Comptes Rendus Biologies, 2006. 329: p. 912-915.

146. Mulder, C., et al., Age structure and senescence in long-term cohorts of Eisenia andrei (Oligochaeta: Lumbricidae). The journals of gerontology. Series A, Biological sciences and medical sciences, 2007. 62(12): p. 1361-3.

147. Murchie, W.R., A contribution on the natural history of Allolobophora minima muldal (Lumbricidae). The Ohio Journal of Science, 1955. 55(4): p. 241-244.

148. Murchie, W.R., Biology of the Oligochaete Eisenia rosea (Savigny) in an Upland Forest Soil of Southern Michigan. American Midland Naturalist, 1958. 60(1): p. 113-131.

149. Murchie, W.R., Biology of the Oligochaete Bismastos zeteki Smith and Gittins (Lumbricidae) in Northern Michigan. American Naturalist, 1960. 64(1): p. 194-215.

150. Nahmani, J., M.E. Hodson, and S. Black, Effects of metals on life cycle parameters of the earthworm Eisenia fetida exposed to field-contaminated metal-pollutes soils. Environmental Pollution, 2007. 149: p. 44-58.

151. Nair, K.V., et al., Biology of cocoons of five species of earthworms (Annelida: Oligochaeta) from Kerala, India. Megadrilogica, 2009. 13(1): p. 1-8.

152. Neaman, A., S. Huerta, and S. Sauvé, Effects of lime and compost on earthworm (Eisenia fetida) reproduction in copper and arsenic contaminated soils from the Puchuncavi Valley, Chile. Ecotoxicology and Environmental Safety, 2012. 80: p. 386-392.

153. Neuhauser, E.F., M.R. Malecki, and R.C. Loehr, Growth and reproduction of the earthworm Eisenia fetida after exposure to sublethal concentrations of metals. Pedobiologia, 1984. 27: p. 89-97.

154. Nogales, R., et al., Growth and reproduction of Eisenia andrei in dry olive cake mixed with other organic wastes. Pedobiologia, 1999. 43: p. 744-752.

155. Nuutinen, V. and K. Butt, The mating behaviour of the earthworm Lumbricus terrestris $L$. (Oligochaeta: Lumbricidae). Journal of Zoology, London, 1997. 242: p. 783-798.

156. Otlavinyte, O., The effect of Erosion on the Population of Earthworms (Lumbricidae) in the Soils under Different Crops. Pedobiologia, 1965. 5: p. 178-188.

157. Owojori, O.J., A.J. Reinecke, and A.B. Rozanov, The combined stress effects of salinity and copper on the earthworm Eisenia fetida. Applied Soil Ecology, 2009. 41: p. 277-285.

158. Owojori, O.J., A.J. Reinecke, and A.B. Rozanov, Influence of clay content on bioavailability of copper in the earthworm Eisenia fetida. Ecotoxicology and Environmental Safety, 2010. 73(3): p. 407-414.

159. Owojori, O.J., et al., Comparative study of the effects of salinity on life-cycle parameters of four soil-dwelling species (Folsomia candida, Enchytraeus doerjesi, Eisenia fetida and Aporrectodea caliginosa). Pedobiologia, 2009. 52(6): p. 351-360. 
160. Panda, S. and S.K. Sahu, Accumulation of zinc and its effects on the growth, reproduction and life cycle of Drawida willsi (Oligochaeta), a dominant earthworm in Indian crop fields. Biology and Fertility of Soils, 1999. 29: p. 419-423.

161. Panda, S. and S.K. Sahu, Assessment of recovery of population, biomass and reproduction of the earthworm Drawida willsi following the application of malathion under field conditions. Biology and Fertility of Soils, 2000. 32: p. 82-88.

162. Parmelee, R.W. and D.A. Crossley, Earthworm production and role in the nitrogen cycle of a no-tillage agroecosystem on the Georgia Piedmont. Pedobiologia, 1988. 32: p. 353-361.

163. Pedersen, M.B. and A. Bjerre, The relationship between mass of newly hatched individuals and cocoon mass in lumbricid earthworms. Pedobiologia, 1991. 35: p. 35-39.

164. Pelosi, C., Modelisation de la dynamique d'une population de vers de terre Lumbricus terrestris au champ. Contribution a l'étude de l'impact de systèmes de culture sur les communautés lombriciennes, 2008, Agro Paris Tech: Paris. p. 98.

165. Pelosi, C., et al., WORMDYN: A model of Lumbricus terrestris population dynamics in agricultural fields. Ecological Modelling, 2008. 218: p. 219-234.

166. Phillips, D.R. and T. Bolger, Sublethal toxic effects of aluminium on the earthworm Eisenia fetida Pedobiologia, 1998. 42: p. 125-130.

167. Podolak, A., et al., Effects of Nickel, Zinc, and Lead-Contaminated Soil on Burrowing Rate and Coelomocytes of the Earthworm, Allolobophora chlorotica. Folia biologica, 2011. 59(3-4): p. 91-97.

168. Reddy, V.M. and M. Pasha, Influence of rainfall temperature and some soil physico-chemical variables on seasonal population structure and vertical distribution of earthworms in two semi-arid tropical grassland soils. International Journal of Biometeorology, 1993. 37: p. 1926.

169. Reinecke, A.J. and J.R. Kriel, Influence of temperature on the reproduction of the earthworm Eisenia foetida (Oligochaeta). South African Journal of Zoology, 1981. 16: p. 96-100.

170. Reinecke, A.J., S.A. Reinecke, and M.S. Maboeta, Cocoon production and viability as endpoints in toxicity testing of heavy metals with three earthworm species. Pedobiologia, 2001. 45(1): p. 61-68.

171. Reinecke, A.J. and J.M. Venter, Influence of dieldrin on the reproduction of the earthworm Eisenia fetida (Oligochaeta). Biology and Fertility of Soils, 1985. 1(1): p. 39-44.

172. Reinecke, A.J. and S.A. Viljoen, Reproduction of the African earthworm, Eudrilus eugeniae (Oligochaeta) - cocoons. Biology and Fertility of Soils, 1988. 7(1): p. 23-27.

173. Reinecke, A.J. and S.A. Viljoen, The influence of worm density on growth and cocoon production of the compost worm Eisenia fetida (Oligochaeta). Revue d'Ecologie et de Biologie du Sol, 1990. 27(2): p. 221-230.

174. Reinecke, A.J. and S.A. Viljoen, Cocoon deposition by the African Nightcrawler Eudrilus eugeniae (Oligochaeta). Pedobiologia, 1993. 37: p. 351-356.

175. Reinecke, A.J. and F.A. Visser, Number and size of hatchlings from cocoons of the earthworm species Eisenia rosea and Allolobophora trapezoides (Oligochaeta). Revue d'écologie et de biologie du sol, 1981. 18(4): p. 473-485.

176. Reinecke, S.A., M.W. Prinsloo, and A.J. Reinecke, Resistance of Eisenia fetida (Oligochaeta) to Cadmium after Long-Term Exposure. Ecotoxicology and Environmental Safety, 1999. 42(1): p. 75-80.

177. Robidoux, P.Y., et al., Assessment of Soil Toxicity from an Antitank Firing Range Using Lumbricus terrestris and Eisenia andrei in Mesocosms and Laboratory Studies. Ecotoxicology, 2004. 13(6): p. 603-614.

178. Römbke, J., M.V. Garcia, and A. Scheffczyk, Effects of the Fungicide Benomyl on Earthworms in Laboratory Tests Under Tropical and Temperate Conditions. Archives of Environmental Contamination and Toxicology, 2007. 53: p. 590-598. 
179. Rouabah, L. and M. Descamps, Biologie des oligochètes Lumbricus terrestris, Allolobophora chlorotica et Dendrobaena pygmea dans le Constantinois (Est Algérien). Bulletin de la Société zoologique de France, 2001. 126(1-2): p. 49-58.

180. Rozen, A., The annual cycle in populations of earthworms (Lumbricidae, Oligochaeta) in three types of oak-hornbean of the Niepolomicka Forest. Pedobiologia, 1988. 31: p. 169-178.

181. Rozen, A., Do earthworms (Dendrobaena octaedra) from differently polluted forests vary in life-history parameters? European Journal of Soil Biology, 2003. 39: p. 73-77.

182. Rozen, A., Internal regulation of reproduction seasonality in earthworm Dendrobaena octaedra (Savigny, 1826) (Lumbricidae, Oligochaeta). Soil Biology \& Biochemistry, 2006. 38(1): p. 180-182.

183. Rundgren, S., Seasonality of Emergence in Lumbricids in Southern Sweden. Oikos, 1977. 28(1): p. 49-55.

184. Rundgren, S. and P. Nilsson, Sublethal effects of aluminium on earthworms in acid soil: the usefulness of Dendrodrilus rubidus (Sav.) in a laboratory test system. Pedobiologia, 1997. 41: p. 417-436.

185. Rushton, S.P., Development of earthworms populations on pasture land reclaimed from open-cast coal mining. Pedobiologia, 1986. 29: p. 27-32.

186. Sahu, S.K. and B.K. Senapati, Alternative proposals for quantification of reproduction in a tropical earthworm. Tropical Ecology, 1988. 29: p. 6-14.

187. Saussey, M., Contribution à l'étude des phénomènes de diapause et de régénération caudale chez Allolobophora icterica : Savigny Oligochète lombricien, 1966, Faculté de sciences de Caen. p. 160.

188. Saussey, M., Cycle de reproduction d'un lombricien anécique : Nicodrilus giardi (Ribaucourt). Ses relations avec les facteurs du milieu. Bulletin de la Société zoologique de France, 1981. 106(3): p. 269-275.

189. Savard, K., et al., Effects of HMX-Lead Mixtures on Reproduction of the Earthworm Eisenia Andrei. Archives of Environmental Contamination and Toxicology, 2007. 53: p. 351-358.

190. Schmidt, O. and J.P. Curry, Population dynamics of earthworms (Lumbricidae) and their role in nitrogen turnover in wheat and wheat-clover cropping systems. Pedobiologia, 2001. 45(2): p. 174-187.

191. Schmidt, O., et al., Earthworm communities in conventional wheat monocropping and lowinput wheat-clover intercropping systems. Annals of Applied Biology, 2001. 138(3): p. 377388.

192. Schneider, A.K. and B. Schroder, Perspectives in modelling earthworm dynamics and their feedbacks with abiotic soil properties. Applied Soil Ecology, 2012. 58: p. 29-36.

193. Schrader, S., Description of the effects on earthworms of redox potential and $\mathrm{pH}$-value with indicators. Mitteilungen der Deutschen Bodenkundlichen Gesellschaft, 1991. 66(1): p. 577580.

194. Scott-Fordsmand, J.J., J.M. Weeks, and S.P. Hopkin, Toxicity of nickel to the earthworm and the applicability of the neutral red retention assay. Ecotoxicology, 1998. 7(5): p. 291-295.

195. Scott-Fordsmand, J.J., J.M. Weeks, and S.P. Hopkin, Importance of contamination history for understanding toxicity of copper to earthworm Eisenia fetida (Oligochaeta: Annelida) using neutral-red retention assay. Environmental Toxicology and Chemistry, 2000. 19(7): p. 17741780 .

196. Senapati, B.K., Aspects of ecophysiological studies on tropical earthworms (Distribution, Population dynamics, Production, Energetics and their role in the decomposition process), in School of Life Science1980, Sambalpur University: Sambalpur. p. 154.

197. Senapati, B.K., et al., Impact of malathion on Drawida willsi, Michaelsen, a dominant earthworm in Indian rice fields. Pedobiologia, 1991. 35: p. 117-128. 
198. Senapati, B.K., S.C. Pani, and S.K. Sahu. Impact of Malathion on the population biology and secondary production of Drawida willsi, Michaelsen, a dominant earthworm in paddy field. in Proc. Nat. Con. Env. Impact on Biosystem. 1987. Madras.

199. Sheppard, P.S., Specific differences in coconn and hatchling production in Eisenia fetida and E. andrei, in Earthworms in waste and environmental management, C.A. Edwards, Editor 1988, SPB Academic Publishing: The Hague, The Netherland. p. 83-92.

200. Simini, M., et al., Reproduction and survival of Eisenia fetida in a sandy loam soil amended with the nitro-heterocyclic explosives RDX and HMX. Pedobiologia, 2003. 47: p. 657-662.

201. Simonsen, V. and J.J. Scott-Fordsmand, Genetic Variation in the Enzyme Esterase, Bioaccumulation and Life History Traits in the Earthworm Lumbricus Rubellus from a Metal Contaminated Area, Avonmouth, England. Ecotoxicology, 2004. 13(8): p. 773-786.

202. Singh, J. and H.K. Chauhan, Effect of tertiary combinations of animal dung with agrowastes on the growth and development of earthworm Eisenia fetida during organic waste management. International Journal of Recycling of Organic Waste in Agriculture, 2013. 2(11).

203. Singh, J., et al., Role of Eisenia fetida in rapid recycling of nutrients from bio sludge of beverage industry. Ecotoxicology and Environmental Safety, 2010. 73(3): p. 430-435.

204. Sivasankari, B., S. Indumathi, and M. Anandharaj, A study on life cycle of Earth worm Eudrilus eugeniae. International Journal of Research in Pharmacy and Life Sciences, 2013. 1(2): p. 6467.

205. Soni, R. and S.A. Abbasi, Mortality and Reproduction in Earthworm Pheritima posthuma Exposed to Chromium (VI). International Journal of Environmental Studies, 1981. 17(2): p. 147-149.

206. Soobhany, N., R. Mohee, and V.K. Garg, Experimental process monitoring and potential of Eudrilus eugeniae in the vermicomposting of organic solid waste in Mauritius. Ecological Engineering, 2015. 84: p. 149-158.

207. Springett, J.A., et al., Population density and distribution of the new zealand indigenous earthworm Octochaetus multiporus (Megascolecidae: Oligochaeta) in hill pastures. New Zealand Journal of Ecology, 1998. 22(1): p. 87-93.

208. Spurgeon, D.J. and S.P. Hopkin, Extrapolation of the laboratory-based OECD earthworm toxicity test to metal-contaminated field sites. Ecotoxicology, 1995. 4(3): p. 190-205.

209. Spurgeon, D.J. and S.P. Hopkin, Effects of variations of the organic matter content and $\mathrm{pH}$ of soils on the availability and toxicity of zinc to the earthworm Eisenia fetida. Pedobiologia, 1996. 40: p. 80-96.

210. Spurgeon, D.J. and S.P. Hopkin, The effects of metal contamination on earthworm populations around a smelting works: Quantifying species effects. Applied Soil Ecology, 1996. 4(2): p. 147-160.

211. Spurgeon, D.J. and S.P. Hopkin, Seasonal variation in the abundance, biomass and biodiversity of earthworms in soils contaminated with metal emissions from a primary smelting works. Journal of Applied Ecology, 1999. 36(1): p. 173-183.

212. Spurgeon, D.J. and S.P. Hopkin, Tolerance to zinc in populations of the earthworm Lumbricus rubellus from uncontaminated and metal-contaminated ecosystems. Archives of Environmental Contamination and Toxicology, 1999. 37(3): p. 332-337.

213. Spurgeon, D.J., S.P. Hopkin, and D.T. Jones, Effects of cadmium, copper, lead and zinc on growth, reproduction and survival of the earthworm Eisenia fetida (Savigny): Assessing the environmental impact of point-source metal contamination in terrestrial ecosystems. Environmental Pollution, 1994. 84(2): p. 123-130.

214. Spurgeon, D.J., et al., Earthworm responses to $\mathrm{Cd}$ and $\mathrm{Cu}$ under fluctuating environmental conditions: a comparison with results from laboratory exposures. Environmental Pollution, 2005. 136(3): p. 443-452. 
215. Spurgeon, D.J., et al., Relative sensitivity of life-cycle and biomarker responses in four earthworms species exposed to Zinc. Environmental Toxicology and Chemistry, 2000. 19(7): p. $1800-1808$.

216. Spurgeon, D.J., et al., Quantifying copper and cadmium impacts on intrinsic rate of population increase in the terrestrial oligochaete Lumbricus rubellus. Environmental Toxicology and Chemistry, 2003. 22(7): p. 1465-1472.

217. Spurgeon, D.J., M.A. Tomlin, and S.P. Hopkin, Influence of Temperature on the Toxicity of Zinc to the Earthworm Eisenia fetida. Bulletin of Environmental Contamination and Toxicology, 1997. 58(2): p. 283-290.

218. Stachowicz, J.J., Mutualism, Facilitation, and the Structure of Ecological Communities. Bioscience, 2001. 51(3): p. 235-246.

219. Stanley, J. and G. Preetha, Pesticide Toxicity to Earthworms: Exposure, Toxicity and Risk Assessment Methodologies, in Pesticide Toxicity to Non-target Organisms: Exposure, Toxicity and Risk Assessment Methodologies2016, Springer Netherlands: Dordrecht. p. 277-350.

220. Striganova, B.R., Determination of food ration in the earthworms Nicodrilus caliginosus and Eisenia nordenskioldi (Lumbricidae, Oligochaeta). Doklady Biological Sciences, 1983. 266(26): p. 521-523.

221. Suthar, S., Nutrient changes and biodynamics of epigeic earthworm Perionyx excavatus (Perrier) during recycling of some agriculture wastes. Bioresource Technology, 2007. 98(8): p. 1608-1614.

222. Suthar, S., Influence of different food sources on growth and reproduction performance of composting epigeics: Eudrilus eugeniae, Perionyx excavatus and Perionyx sansibaricus. Applied Ecology and Environmental Research, 2007. 5(2): p. 79-92.

223. Suthar, S., Potential of Allolobophora parva (Oligochaeta) in vermicomposting. Bioresource Technology, 2009. 100(24): p. 6422-6427.

224. Suthar, S. and S. Singh, Vermicomposting of domestic waste by using two epigeic earthworms (Perionyx excavatus and Perionyx sansibaricus). International Journal of Environment Science and Technology, 2008. 5(1): p. 99-106.

225. Svendsen, C., et al., Effect of temperature and season on reproduction, neutral red retention and metallothionein responses of earthworms exposed to metals in field soils. Environmental Pollution, 2007. 147(1): p. 83-93.

226. Svendsen, T.S., et al., Life history characteristics of Lumbricus terrestris and effects of the veterinary antiparasitic compounds ivermectin and fenbendazole. Soil Biology \& Biochemistry, 2005. 37(5): p. 927-936.

227. Tejada, M., et al., Response of Eisenia fetida to the application of different organic wastes in an aluminium-contaminated soil. Ecotoxicology and Environmental Safety, 2010. 73(8): p. 1944-1949.

228. Thi Thanh Binh, T. and N. Thi Hien, Initial result of the raising Di Long (Earthworms) (Pheritima aspergillum Perrier,1872). journal of Science of Hnue, 2011. 56(7): p. 144-151.

229. Tomlin, A.D., D. McCabe, and R. Protz, Species composition and seasonal variation of earthworms and their effect on soil properties in southern Ontario, Canada. Soil Biology \& Biochemistry, 1992. 24(12): p. 1451-1457.

230. Tomlin, A.D. and J.J. Miller. Development and fecundity of the manure worm, Eisenia foetida (Annelida: Lumbricidae), under laboratory conditions. in Soil biology as related to land use practices. Proceedings of the 7th. International Colloquium of Soil Zoology. 1980. Syracuse: EPA.

231. Uvarov, A.V., Responses of an earthworm species to constant and diurnally fluctuating temperature regimes in laboratory microcosms. European Journal of Soil Biology, 1995. 31(2): p. 111-118. 
232. Uvarov, A.V., A.V. Tiunov, and S. Scheu, Effects of seasonal and diurnal temperature fluctuations on population dynamics of two epigeic earthworm species in forest soil. Soil Biology \& Biochemistry, 2010. 43(3): p. 559-570.

233. Valle, J.V., et al., Annual dynamics of the earthworm Hormogaster elisae (Oligochaeta, Hormogastridae) in central Spain. Soil Biology \& Biochemistry, 1997. 29(3/4): p. 309-312.

234. van der Ploeg, M.J.C., et al., Effects of $C_{60}$ nanoparticle exposure on earthworms (Lumbricus rubellus) and implications for population dynamics. Environmental Pollution, 2011. 159(1): p. 198-203.

235. van Gestel, C.A.M., E.M. Dirven-van Breemen, and R. Baerselman, Influence of environmental conditions on the growth and reproduction of the earthworm Eisenia andrei in an artificial soil substrate. Pedobiologia, 1992. 36: p. 109-120.

236. van Gestel, C.A.M., et al., Comparison of Sublethal and Lethal Criteria for Nine Different Chemicals in Standardized Toxicity Tests Using the Earthworm Eisenia andrei. Ecotoxicology and Environmental Safety, 1992. 23(2): p. 206-220.

237. van Gestel, C.A.M., et al., Comparison of two methods for determining the viability of cocoons produced in earthworms toxicity experiments. Pedobiologia, 1988. 32: p. 367-371.

238. van Gestel, C.A.M., et al., Development of a standardized reproduction toxicity test with the earthworm species Eisenia fetida andrei using copper, pentachlotophenol, and, 2,4dichloroaniline. Ecotoxicology and Environmental Safety, 1989. 18: p. 305-312.

239. van Gestel, C.A.M., et al., Comparison of two test methods for determining the effects of pesticides on earthworm reproduction. Acta Zoologica Fennica, 1995. 196: p. 278-283.

240. van Praagh, B.D. and S.D. Hinkley, Survey of the Giant Gippsland Earthworm, Megascolides australis in areas potentially affected by a realignment of the South Gippsland HighwayBena to Korumburra, in Museum Victoria Science Reports2002, Museum Victoria: Melbourne. p. 1-5.

241. Vasanthi, K., et al., Influence of temperature on growth and reproduction of earthworm Eudrilus eugeniae. International Journal of Current Microbiology and Applied Sciences, 2013. 2(7): p. 202-206.

242. Velando, A., J. Dominguez, and A. Ferreiro, Inbreeding and outbreeding reduces cocoon production in the earthworm Eisenia andrei. European Journal of Soil Biology, 2006. 42: p. S354-S357.

243. Venter, J.M. and A.J. Reinecke, Effects of the pesticide dieldrin on incubation of the earthworm Eisenia fetida (Oligochaeta). South African Journal of Zoology, 1987. 22(2): p. 97100.

244. Vijayabaskaran, S. and A.K. Mani. Optimising feed composition to enhance growth and reproduction rate of earthworm (Eudrilus eugeniae). in 5th International Crop Science Congress. 2008. Jeju, Korea: International Crop Science Society.

245. Viljoen, S.A. and A.J. Reinecke, Moisture preferences, growth and reproduction of the African nightcrawler, Eudrilus eugeniae (Oligochaeta). South African Journal of Zoology, 1990. 25(3): p. 155-160.

246. Vogel, J. and J.C.G. Ottow, Einfluss unterschiedlicher Fluoride in sublethalen Konzentrationen auf Wachstum, Fertilität und Fluorid-Akkumulation von Eisenia fetida (Influence of different fluorides in sublethal concentrations on growth, fertility and fluoride-accumulation of Eisenia fetida (Oligochaeta, Lumbricidae)). Pedobiologia, 1992. 36: p. 121-128.

247. Vorpahl, P., S. Moenickes, and O. Richter, Modelling of spatio-temporal population dynamics of earthworms under wetland conditions-An integrated approach. Ecological Modelling, 2009. 220(24): p. 3647-3657.

248. Whalen, J.K. and R.W. Parmelee, Growth of Aporrectodea tuberculata (Eisen) and Lumbricus terrestris L. under laboratory and field conditions. Pedobiologia, 1999. 43: p. 1-10. 
249. Whalen, J.K., R.W. Parmelee, and C.A. Edwards, Population dynamics of earthworm communities in corn agroecosystems receiving organic or inorganic fertilizer amendments. Biology and Fertility of Soils, 1998. 27: p. 400-407.

250. Xie, X.C., et al., Effects of decabromodiphenyl ether (BDE-209) on the avoidance response, survival, growth and reproduction of earthworms (Eisenia fetida). Ecotoxicology and Environmental Safety, 2013. 90: p. 21-27.

251. Zajonc, I., Dynamique saisonnière des synusies de lombrics (Lumbricidae) vivant dans les prairies de la Slovaquie méridionale; action des engrais azotés sur la composition de celles-ci. Pedobiologia, 1970. 10: p. 286-304.

252. Zhang, B., et al., Effect of two major N-nitroso hexahydro-1,3,5-trinitro-1,3,5-triazine (RDX) metabolites on earthworm reproductive success. Environmental Pollution, 2008. 153(3): p. 658-667.

253. Zhang, H., X.-D. Yang, and Y.X. Wu, Influence of Soil Temperature and Moisture on the Cocoon Production and Hatching of the Exotic Earthworm Pontoscolex corethrurus. Zoological Research, 2008. 29(3): p. 305-312. 


\section{Checklist for reporting growth curves of Earthworms}

\section{Reference : Mathieu J. Soil Biology and Biochemistry 2018}

https://doi.org/10.1016/i.soilbio.2018.04.004

\section{Experimental design}

The treatments are clearly defined.

The treatment levels are clearly defined.

The number of replicates per treatment is clearly indicated.

The number of individuals per replicate is clearly indicated.

\section{Biomass}

The type of biomass is clearly mentioned (dry vs fresh biomass).

The gut content status is mentioned (void gut vs non voided gut).

The unit of the biomass is given.

"Growth" and "biomass" are used appropriately.

The biomass at hatchling is reported.

The biomass at first date of the survey is given numerically (not only on graphs), with the error bar.

\section{Bonus}

Gut content was estimated.

Body moisture was estimated.

\section{Age and time}

The age of the individuals at the first measurement is clearly given.

The meaning of the $\mathrm{X}$ axis (age or time since the beginning of the measures) is defined.

The units of the time/age axis are clearly mentioned (e.g. days, weeks).

\section{If IGR (Instantaneous growth rate) only is reported,}

Its formula is mentioned.

The absolute biomass are also reported.

The age at each measurement is reported.

\section{Phenology}


Full clitellum development is indicated.

Death of individuals is indicated.

\section{Taxonomy}

A couple of individuals are stored in alcohol for molecular identification.

\section{Conditions of the experiments (metadata)}

All these information are reported:

Geographical origin of the specimens.

Geographical coordinates in decimal degrees.

The system of coordinates.

Country were specimens were sampled.

Species name, with the descriptor.

Air temperature $\left({ }^{\circ} \mathrm{C}\right)$.

Soil or substrate $\mathrm{pH}$.

pH measurement type(e.g. $\mathrm{H} 20, \mathrm{KCl})$.

Container volume.

Substrate mass or volume.

Soil and substrate moisture.

Type of moisture measurement.

Type of food given.

Amount of food given.

Sampling scheme (I,II or III, see figure 4).

Stages covered by the monitoring (B,J, JR,JRS,JRSD and so on, see figure 4).

\section{Data}

Raw data and metadata are available either as supplementary material or in a data repository.

Data are presented in txt or csv files.

Data are given at the highest resolution possible (either by individual or by replicate) rather than as average per treatment.

Error bars are given if averaged data are presented.

The nature of errors bar is clearly stated. 